\title{
KAYSERi/GESi MEZARLıĞı MEZAR TAŞLARI ÜZERINE BiR DEĞERLENDIRME
}

\section{An Evaluation on the Gravestones of the Gesı Cemetery in Kayseri}

\section{Dr. Şerife TALi ${ }^{*}$}

Öz

Bu çalışmada Gesi Mezarlığında yer alan Osmanlı Dönemine ait 47 mezar ve mezartaşları sanat tarihi açısından belgelenerek değerlendirilmiştir. Bu örnekler fotoğraflanarak kitabeleri okunmuş, mezartaşlarının başlık tipleri ve bezeme özellikleri ele alınarak Türk mezar taşı sanatı içerisindeki yerleri belirlenmeye çalışılmıştır. Bu mezartaşları XVIIl. yy., XIX yy. ve XX. yy a tarihlenir. Osmanlı mezar taşları estetik görünümleri ile meslekler, unvanlar ve inanışlarla ilgili önemli bilgiler vermektedir. Bu mezarlıktaki şahidelerin, mezar taşı yapma geleneğini devam ettiren sade örnekler olduğu görülmüştür.

Anahtar Sözcükler: Mezarlık, Mezar taşı, lahit, kitabe, hat, sanat.

\section{ABSTRACT}

This study analyzes the 47 graves and gravestones of the at Cemetery of Gesi which belong to the Ottoman period, this analysis is made from the viewpoint of art history. This gravestones tries to identify the place of these elements in the Turkish gravestones by producing photographic documentation and by discussing the gravestone typologies and their ornamental features. The gravestones dates to the XVIII th, XIX th, and $X X$ th. centuries. With the aesthetic appearance of Ottoman gravestones provides important information that occupations, titles, and about beliefs. Gravestones of this cemetery to be seen simply examples that perpetuates the tradition of making gravestone.

Key Words: Cemetery, gravestone, tomb, inscription, calligraphy, art.

\section{Giriş}

Erciyes Dağının doğu yönünde uzun bir vadinin kenarında kurulan Gesi, Kayseri'nin kuzeydoğusunda ve şehre yaklaşık $18 \mathrm{~km}$. uzaklıktadır. Kocasinan ilcçesine bağlı Gesi'nin en eski tarihçesi konusunda net bilgiler olmamakla birlikte "Kaleböğrü" denilen yerdeki mağaralardan hareketle, tarihi Neolitik Döneme kadar indirilmektedir. C. Texier'in Küçük Asya Seyahatinde "GiSCiSSA" adlı önemli şehrin Gesi ile benzerliğine dikkat çekilmektedir. Karye-i Gâssi olarak ta eski vakfiyelerde geçen Gesi, çevresinin korunaklı coğrafyası sayesinde tarih boyunca Hıristiyan, Beylikler ve Osmanlı Dönemlerinin hüküm sürdüğü, yörede kalan tarihi eserlerden anlaşılmaktadır (Özdoğan: 1948, 74-75; İmamoğlu: 2010, 8-25; Beşbaş: 2006, 9).

Türklerde, İslam öncesinde Şamanizm etkisi ile gelişen mezar geleneği, dönemlere göre farklılıklar göstererek devam etmiştir. İslamiyet'in kabul edilmesiyle birlikte mezar kültürü ve mimarisi dinin etkisiyle farklı boyutlara ulaşmış, aynı zamanda Orta Asya etkilerinin de sürdüğü kurganlar, balballar çeşitli anıt mezarlar, Gök Tanrı ve ölümden

*Ordu Üniversitesi Fen-Edebiyat Fakültesi Sanat Tarih Bölümü, Ordu, talisanat@hotmail.com. 
$360^{*}$ TAED 49 Șerife TALI

sonraki hayat bilinci ile mezarlar şekillenmiştir. Anadolu'nun Türkleşmesi ile birlikte Anadolu Selçuklu, Anadolu Beylikler ve Osmanlı dönemlerinde mezar anıtlarının yapımı gelişerek devam ettirilmiştir. Ölen kişiyi ölümsüzleştirmek adına yapılan mezar taşları da dönemlere göre mimari, form ve farklı bezeme düzenleri ile biçimlenmiş sanat tarihindeki yerini almış küçük eserlerdir (Başkan: 1996, 9-13; Karamağaralı: 1992, 1; Mermutlu-Öcalan: 2011, 13-21)

\section{Mezar Taşı No: 1}

\section{Fotoğraf No: 1}

Kitabesi:

“Hüvel'l-Hallaku'l Baki

Pir Ekrem Halil Efendinin zevcesi

Eşref Hanında Kadim Kişi

Hatice Hanım Mal ile Göçme...Etdi

Bir adet Zımmıle....... ?......Tarihini

Cenneti Firdevs de Kıla Mihman Mevla Seni

Sene 1251/(1836)"

Tipi: Şahideli, çatma lahit mezardır.

Ölçü: Baştaşı boy: 187 cm., en: 40 cm., kalınlık: 15 cm., Ayaktaşı boy: 163 cm., en: 37 cm., kalınlık: $13 \mathrm{~cm}$., lahit: 75×220 cm.

Kesme küfeki taştan yapılan şahideli mezar, üzeri açık bir lahitten oluşmaktadır. Lahitin yan yüzleri ve şahidelerin oturduğu kısımlar basit birer silme ile çerçevelenmiştir. Baş ve ayak taşlarının alt kısmında çarkıfelek motiflerinin izleri bulunurken geniş yan yüzler tamamen tahrip olmuştur.

Baştaşı: Dikdörtgen kesitli düşey dikdörtgen gövdeli baş taşının üzerine yedi satırlık sülüs hatlı kitabe yer alır. Kitabeyi oluşturan satırlar yatay dikdörtgen kartuşlar halinde, sade panolar içerisine kabartma olarak yazılmıştır. Serlevhanın çerçeve düzeni ve içerisindeki yazının istifi diğer satırlardan farklı ele alınmıştır. Baştaşının sivri formlu tepeliği üzerine dilimli bir vazo ve içerisine barok karakterde yapraklar işlenmiştir. Vazodan çıkan bu soyut yapraklar, yanlara "C" kıvrımları oluşturacak şekilde taşarak tüm alanı doldurmuştur.

Ayaktaşı: Baştaşı ile aynı formda ele alınan ayaktaşı sade ve sandukaya bitiştiği kısım tahrip olmuştur.

\section{Mezar Taşı No: 2}

\section{Fotoğraf No: 2}

Kitabesi:

$$
\begin{aligned}
& \text { “Sahibül A'mil vel Arifa'n } \\
& \text { Bi Hakkı Tercüman El-Kur'an } \\
& \text { Eden El Hacı Abdurrahman } \\
& \text { Efendi Merhum Ruhiyçün } \\
& \text { El Fatiha } \\
& \text { Sene } 1309 /(1892) \text { ” }
\end{aligned}
$$

Tipi: Şahideli, çatma lahit mezardır. 
Ölçü: Baştaşı boy: 185 cm., en: 107-60-38 cm., kalınlık: 15 cm., Ayaktaşı boy: $180 \mathrm{~cm}$., en: 107-60-38 cm., kalınlık: $15 \mathrm{~cm}$., lahit: $140 \times 245 \mathrm{~cm}$.

Yöreye özgü küfeki taşla yapılan büyük boyutlu lahitin üzeri açıktır. Üst kısımda silmelerle sınırlanan mezarın baş ve ayak taşlarının alt kısımlarında birer, geniş yan yüzlerinde ise ikişer kabartma panoya yer verilmiştir. Kenarlarda ovalleşen bu panoların içerisine stilize edilmiş şua motifi, motifin ortasına ise ay-yıldız işlenmiştir. Döneme özgü motiflerin kullanıldığı lahitte bazı tahribatlar olmakla birlikte, sağlamdır.

Baştaşı: iki bölüm şeklinde bir düzenlemeye sahip olan baştaşı, lahitle birleştiği kısımdan üste dalgalı formda daralarak devam ettirilmiştir. Baştaşının oturtulduğu dalgalı kaide kenarlarda silmelerle sınırlanarak ortasına daire ve içerisine altı kollu bir yıldız işlenmiştir. Dikdörtgen biçimli gövde yuvarlak formlu bir zeminle kaideden ayrılır şekilde düzenlenerek üzerine altı satırlık sülüs hatlı kitabe yazılmıştır. Kabartma olarak yazılan bu satırlar düz silmelerle ayrılarak dikdörtgen panolarla çerçevelenmiştir. Baştaşı, üstte $70 \mathrm{~cm}$. çapında kavuklu bir serpuşla sonlanmıştır.

Ayaktaşı: Baştaşı ile aynı biçimde ele alınan ayaktaşı üstte sivri formlu olarak sonlanmıştır.

\section{Mezar Taşı No: 3}

Fotoğraf No: 3

Kitabesi: ‘Hüvel'l-Hallaku'l Baki Miskinim Dağ Başı Sahraya Hacet Kaldı mı Iç̧tim Ecel Şarabını Lokmana Hacet Kalmadı Kayserili Büyük Zade Osman Efendinin Mahdumu ìsmail Hakkı

Sene 1327/(1894) Şevval Efendinin Ruhuna Fatiha Sene 1312/(1909)

(hamse ve tis-e mie)"

Tipi: Şahideli, çatma lahit mezardır.

Ölçü: Baştaşı boy: $72 \mathrm{~cm}$., en: $31 \mathrm{~cm} .$, kalınlık: $10-20 \mathrm{~cm}$., Ayaktaşı boy: $72 \mathrm{~cm}$., en: 87-52-25 cm., kalınlık: $20 \mathrm{~cm}$. , lahit: $87 \times 228 \mathrm{~cm}$.

Küfeki taştan yapılan lahitin üzeri açık olup tüm yüzeyi kazıma tekniğindeki silmelerle sınırlanmıştır. Lahitin dar ve geniş yüzeylerindeki bu çerçevelerin içerisine kazınan baklava motifleri ile hareketlilik sağlanmıştır.

Baştaşı: Muhtemelen orijinal şahide üzerine sonradan yerleştirilen, dikdörtgen formlu mermer baştaşı, üste doğru genişleyen formda ele alınmıştır. Şahidenin üzerine diagonal olarak altı satırlık ta'lik hatlı kitabe yazılmıştır. Silmelerle çerçevelen kabartma olarak yazılan kitabenin ilk satırı, kartuş şeklinde düzenlenmiştir. Şahidenin üzerine kısa tutulan $65 \mathrm{~cm}$. çapında şerit sarıklı bir serpuş yerleştirilmiştir.

Ayaktaşı: Baştaşı ile aynı formda ele alınan ayaktaşının yüzeyi bitkisel bir kompozisyonla bezenmiştir. Bir silme ile sınırlanan yüzeyin ortasına kaideli, lale formunda bir vazo konmuştur. Vazonun içerisinden farklı boyutlarda çıkarak yukarı doğru yükselen dallar stilize yapraklarla hareketlendirilmiştir. Kompozisyonda tam ortada yer alan 
dal yukarı helezon yaparak uzatılmış ve ucuna küpe çiçeği takılmıştır. Diğer dalların uçlarına da farklı büyüklükte küpe çiçekleri eklenerek bitkisel kompozisyon daha da zenginleştirilmiştir.

\title{
Mezar Taşı No: 4
}

Fotoğraf No: 4

\section{Kitabesi:}

\author{
“Hüve'l-Hallaku'l Baki \\ Merhum ve Mağfur \\ Veksevi Muhammed Efendi \\ Ruhiyçün El Fatiha \\ Sene 1235/(1820)"
}

Tipi: Şahideli, çatma lahit mezardır.

Ölçü: Baştaşı boy: 130 cm., en: 50 cm., kalınlık: 20 cm., Ayaktaşı boy: 125 cm., en: 42$50 \mathrm{~cm}$., kalınlık: $20 \mathrm{~cm}$., lahit: 76×252 cm.

Yöreye özgü taşla yapılanan lahit oldukça sade ve üzeri açıktır. Sağlam durumdaki lahitin baş ve ayak şahideleri yekpare olup yan yüzleri de hiç işlenmemiştir.

Baştaşı: Dikdörtgen kesitli düşey dikdörtgen gövdeli baş taşının üzerinde beş satırlık sülüs hatlı kitabe yer alır. Kitabeyi oluşturan satırlar yatay dikdörtgen formlu sade panolarla çerçevelenmiş ve yazılar kabartma olarak yazılmıştır. Alttaki beşinci satır aşağı doğru üçgen biçimli bir kartuşla hareketlendirilmiştir. Şahidenin iç kısmına kitabeli yüzeyin aynısı çizgilerle belirlenmiş ve bitirilemeden bırakılmıştır. Baştaşı üstte kısa tutulan $120 \mathrm{~cm}$. çapında sarıklı bir başlıkla sonlanmıştır.

Ayaktaşı: Baştaşı ile aynı formda ele alınan ayaktaşı üstte doğru daralarak sivri formlu olarak sonlanmıştır. Ayaktaşı tamamen sade olup herhangi bezemesi yoktur.

\section{Mezar Taşı No: 5}

\section{Fotoğraf No: 5}

Kitabesi:

$$
\begin{aligned}
& \text { “Hüve'l-Hallaku'l Baki } \\
& \text { Merhum ve Mağfur leh } \\
& \text { Osman Efendi Zade } \\
& \text { El Hacı Şükrü Efendi } \\
& \text { Ruhiyçün El Fatiha } \\
& \text { Sene 1265/(1848)” }
\end{aligned}
$$

Tipi: Şahideli, çatma lahit mezardır.

Ölçü: Baştaşı boy: 183 cm., en: 118-110-37 cm., kalınlı: 11-7 cm., lahit: 153×258 cm.

Bir kaide üzerine oturtulan küfeki taşla yapılan lahit, büyük boyutlu ve üzeri açıktır. Baş ve ayak taşlarının alt kısımları tamamen tahrip olan lahitin tüm yüzeyi üstte silmelerle çerçevelenmiştir. Lahitin geniş yan yüzlerinde kabartma olarak birbiriyle bağlantılı, iki pano işlenmiş̧ir. İçleri boş bırakılan panoların tahrip olan dar yüzlerde tekli olarak uygulanmış olması muhtemeldir. 
Baştaşı: Lahit ile birleştiği kısımdan itibaren üste doğru dalgalı formda daralarak devam eden baştaşı, dikdörtgen formlu olarak tamamlanmıştır. Altta kaide havasında yapılan bu kısım üzerinde yer alan derinliği ve formu farklı olan baştaşı iki bölüm şeklinde bir düzenlemeye sahiptir. Kenarları içe ve dışa kıvrımlı kaide kısmının ortasına altı kollu bir yıldız motifi bezenmiştir. Baştaşı üzerine de silmelerle sınırlanan altı satırlık sülüs hatlı kitabe yazılmış, son satır oval kartuş şeklinde düzenlenmiştir. Sade olan şahide üzerine $100 \mathrm{~cm}$. çapında sarıklı bir serpuş yerleştirilmiştir.

Ayaktaşı: Ayaktaşı mevcut değildir.

\section{Mezar Taşı No: 6}

\section{Fotoğraf No: 6}

Kitabesi: “Hüve'l-Hallaku'l Baki

Ya Rahman Bu Așrı Makamı

Mahmuden Halis Efendi

Zade Osman Efendi

Ruhiyçün El Fatiha

Sene $1248 /(1832)$

Fi 15 ..."

Tipi: Şahideli, çatma lahit mezardır.

Ölçü: Baştaşı boy: 118 cm., en: 71-40 cm., kalınlık: 7 cm., Ayaktaşı boy: 125 cm., en: 37 cm., kalınlık: $16 \mathrm{~cm}$., lahit: $78 \times 271 \mathrm{~cm}$.

Bir kaide üzerine oturtulan küfeki taşla yapılan lahit sade olup üzeri açıktır. Bazı tahribatların olduğu dikdörtgen formlu lahiti oluşturan şahideler yekparedir.

Baştaşı: Yekpare olarak ele alınan baştaşının kareye yakın dikdörtgen biçimli alt bölüm üst kısma doğru daralarak dikdörtgen formda tamamlanmıştır. Şahidenin gövdesinde altı satırlık sülüs hatlı kitabe, dikdörtgen panolar içerisine kabartma şeklinde yazılmıştır. Son satırda yer alan tarih ibaresi dikdörtgen kartuş içerisine alınmıştır. Sade tutulan şahideye, üstte $16 \mathrm{~cm}$. yükseklikte boyun ve üzerine de $110 \mathrm{~cm}$. çapında sarıklı bir serpuş yerleştirilmiştir.

Ayaktaşı: Baştaşı ile aynı formda ele alınan ayaktaşı üstte sivri formlu olarak sonlanmıştır. Ayaktaşı sade bir düzenlemeye sahiptir.

\section{Mezar Taşı No: 7}

Fotoğraf No: 7

Kitabesi: "Merhuman

Humbaracı Zade

Osman Efendi

Ve Kerimesi Akkadın

Ruhlarıyçün Fatiha

Sene 1312/(1894) Sene 1255/(1839)"

Tipi: Şahideli, çatma lahit mezardır. 
Ölçü: Baştaşı boy: $130 \mathrm{~cm}$., en: 40-69 cm., kalınlık: $19 \mathrm{~cm}$., Ayaktaşı boy: $115 \mathrm{~cm}$., en: $37 \mathrm{~cm}$., kalınlık: $18 \mathrm{~cm}$., lahit: $68 \times 228 \mathrm{~cm}$.

Bir kaide üzerine oturtulan küfeki taşla yapılan lahit, sade ve üzeri açıktır. Sağlam durumdaki dikdörtgen planlı lahitin şahideleri yekparedir.

Baştaşı: Yekpare olarak ele alınan baştaşının kareye yakın dikdörtgen biçimli alt bölüm üst kısımda üçgen şekilde pahlanarak devam ettirilmiş, baştaşı dikdörtgen kesitli düşey dikdörtgen gövdeli olarak tamamlanmıştır. Baştaşının üzerinde altı satırlık sülüs hatlı kitabe kuşakları, dikdörtgen formlu panolar içerisine kabartma olarak yazılmıştır. Tarih ibaresinin de bulunduğu kitabeyi oluşturan son iki satır diğer satırlara göre daha geniş tutulmuştur. Sade olan şahidenin üzerine de $13 \mathrm{~cm}$. yükseklikte boyun ve $95 \mathrm{~cm}$. çapında sarıklı bir başlık yerleştirilmiştir.

Ayaktaşı: Baştaşı ile aynı formda biçimlenen ayaktaşı, üstte doğru daralarak sivri olarak sonlanmıştır. Ayaktaşı bezemesizdir.

\title{
Mezar Taşı No: 8
}

Fotoğraf No: 8

Kitabesi:

\author{
“Hüvel'l-Hallaku'l Baki \\ Merhum Es-Seyyid \\ Hasan Ağa Ruhiyçün
}

El Fatiha

Sene $1219 /(1805)$

Zel? 15"

Tipi: Şahideli, çatma lahit mezardır.

Ölçü: Baştaşı boy: 143 cm., en: 38 cm., kalınlık: 10 cm., Ayaktaşı boy: 135 cm., en: 32 cm., kalınlık: $15 \mathrm{~cm}$., lahit: 64×243 cm.

Bir kaide üzerine yerleştirilmiş baş ve ayak şahideleri bulunan çatma lahitin üzeri açıktır. Küfeki taşla yapılan dikdörtgen planlı sade lahitin şahideleri yekparedir.

Baştaşı: Yekpare olarak ele alınan baştaşının kareye yakın dikdörtgen biçimli alt bölüm üstte oval olarak pahlanmış ve gövde kısmı dikdörtgen formda şekillenmiştir. Şahidenin yüzeyinde beş satırlık sülüs hatlı kitabe kabartma olarak yazılmıştır. Bu satırlar silmelerle sınırlanan dikdörtgen formlu panolarla çerçevelenmiş, tarih ibaresinin olduğu son satır yarım yuvarlak bir silme ile hareketlendirilmiştir. Sade tutulan baştaşı, üzerine yerleştirilmiş $14 \mathrm{~cm}$. yükseklikteki boyun ve $105 \mathrm{~cm}$. çapında çubuk başlıklı taşkın sarıklı bir serpuşla sonlanmıştır.

Ayaktaşı: Baştaşı ile aynı formda biçimlenen ayaktaşı üstte doğru daralarak devam ettirilmiş ve sivri formda sonlanmıştır. Ayaktaşı sadedir.

\section{Mezar Taşı No: 9}

Fotoğraf No: 9

Kitabesi: “Hüv'el Baki

Merhum ve Mağfur 


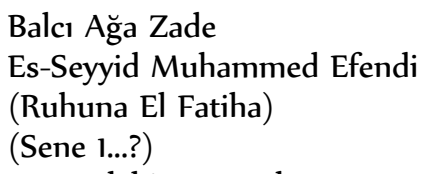

Tipi: Şahideli, çatma lahit mezardır.

Ölçü: Baştaşı boy: 110 cm., en: 43 cm., kalınlık: 7 cm., Ayaktaşı boy: 110 cm., en: 35 cm., kalınlık: $10 \mathrm{~cm}$., lahit: $70 \times 224 \mathrm{~cm}$.

Baş ve ayak şahideleri bulunan dikdörtgen planlı taş lahit toprağa gömülü vaziyettedir. Üstte açıkta kalan sandukanın sade bir düzenlemeye sahip olduğu anlaşılmaktadır.

Baştaşı: Yekpare olarak ele alınan baştaşının kareye yakın dikdörtgen biçimli alt bölüm üst kısımda pahlarla ayrılmış ve gövde dikdörtgen formlu olarak tamamlanmıştır. Şahidenin üzerindeki beş satırlık sülüs hatlı kabartma kitabe, sade dikdörtgen panolar içerisine yazılmıştır. Kitabenin ilk satırında serlevha farklı düzenlemiş, tarih ibaresinin olduğu son satır ise tamamen erimiştir. Sade baştaşının üzerine de $16 \mathrm{~cm}$. yükseklikte boyun ve $96 \mathrm{~cm}$. çapında kavuklu bir serpuş yerleştirilmiştir.

Ayaktaşı: Baştaşı ile aynı formda biçimlenen ayaktaşı üstte doğru daralarak devam ettirilmiş ve sivri formda sonlanmıştır. Ayaktaşı sadedir.

Mezar Taşı No: 10

Fotoğraf No: 10

Kitabesi: "Balcı Ali Ağa Ruhiyçün Fatiha Sene 1223/(1808)"

Tipi: Şahideli, çatma lahit mezardır.

Ölçü: Baştaşı boy: 120 cm., en: 35-47 cm., kalınlık: 8 cm., lahit: 58x224 cm.

Baş ve ayak şahideleri bulunan dikdörtgen planlı taş lahit sade ve üzeri açıktır. Lahitin bir kısmı ve baştaşı günümüze gelebilen mezar büyük oranda tahrip olmuştur.

Baştaşı: Yekpare olarak ele alınan baştaşının kareye yakın dikdörtgen biçimli alt bölüm üst kısımda köşeleri pahlanarak ayrılmış ve gövde üstte oval olarak tamamlanmıştır. Geniş olan gövde yüzeyinde tek satırlık sülüs hatlı kitabe ve tarih ibaresi kabartma olarak yazılmıştır. Bu iki satır dışında şahidenin yüzeyi boş olup herhangi bezeme yoktur. Baştaşının üzerine de $12 \mathrm{~cm}$. yükseklikte bir boyun ve $110 \mathrm{~cm}$. çapında çubuk başlıklı, taşkın sarıklı bir serpuş yerleştirilmişstir.

Ayaktaşı: Ayaktaşı mevcut değildir.

\section{Mezar Taşı No: 11}

Fotoğraf No: 11

Kitabesi: “Hüvel'l-Hallaku'l Baki

Merhum ve Mağfur

Humbaracı Zade 
Hacı Mehmed

Ağa Ruhiyçün

El Fatiha

Sene 1305/(1887)"

Tipi: Şahideli, çatma lahit mezardır.

Ölçü: Baştaşı boy: 122 cm., en: 38 cm., kalınlık: 19 cm., Ayaktaşı boy: 120 cm., en: 38 cm., kalınlık: $20 \mathrm{~cm}$. , lahit: $68 \times 200 \mathrm{~cm}$.

Baş ve ayak şahideleri bulunan çatma lahit sade ve üzeri açıktır. Genel olarak sağlam durumdaki dikdörtgen planlı taş lahitin şahideleri yekparedir.

Baştaşı: Yekpare olarak ele alınan baştaşının kareye yakın dikdörtgen biçimli alt bölüm üst kısımda üçgen şekilde pahlanarak devam ettirilmiştir. Baştaşı dikdörtgen biçimli ve üstte silindirik olarak tamamlanmıştır. Şahidenin dış yüzü boş bırakılırken kitabe farklı olarak burada iç yüze yazılmıştır. Dıştan bir silme ile sınırlanan baştaşı alt ve üst kısımlarda yarım yuvarlak formlu silmelerle çerçevelenmiştir. Şahidenin üzerine yedi satırlık sülüs hatlı kitabe, dikdörtgen panolar içerisine kabartma olarak yazılmıştır. Sade olan baştaşının üzerine de $9 \mathrm{~cm}$. yükseklikte boyun ve $32 \mathrm{~cm}$. çapında sarıklı bir başlık yerleştirilmiştir.

Ayaktaşı: Baştaşı ile aynı formda ele alınan ayaktaşı tamamen sadedir.

Mezar Taşı No: 12

Fotoğraf No: 12

Kitabesi: Cana Zevvar Düşüp Mevti Hayattır Dünyanda

Okusun Fatiha (muhtaca bu )

Ali Efendinin Oğlu Ömer Beydir Şehid Med'fun

Edip Rıhlet Can içre Gör Lütfünü Mevla'nın

Yaza.......Evla Fi Dedim Tarih

Habibin Aşkına Mevla Merhum Mağfur Bulunan

Sene $1227 /(1812) "$

Tipi: Şahideli, toprak mezardır.

Ölçü: Baştaşı boy: 130 cm., en: 42-68 cm., kalınlık: $15 \mathrm{~cm}$.

Baştaşı: Yekpare olarak ele alınan baştaşının kareye yakın dikdörtgen biçimli alt bölüm üst kısımda üçgen şekilde pahlanmış ve altta dar dikdörtgen biçimli üstte genişleyerek oval olarak tamamlanmıştır. Baştaşının üzerindeki yedi satırlık sülüs hatlı kitabe, kabartma olarak yazılmış ve satırlar düz silmelerle ayrılan panolarla çerçevelenmiştir. Tarih ibaresinin olduğu son satır diğerlerine göre daha dar tutulmuştur. Sade olan baştaşının üzerine de $14 \mathrm{~cm}$. yükseklikte boyun ve $95 \mathrm{~cm}$. çapında kısa sarıklı bir serpuş yerleştirilmiştir.

Ayaktaşı: Ayaktaşı mevcut değildir.

\section{Mezar Taşı No: 13}


Fotoğraf No: 13

Kitabesi: "Ya Rahman Bu Aşır Makama

Mahmuden Bi Hürmeti Mehmed

Halis Mehmed Efendi

Ruhiyçün Fatiha

fi 9 Sene $1211 /(1796)$

Sabıka Bu Kabirde Medfun

Hacı Osman Dede Ru-

Hıyçün Fatiha

Sene 1155 ?/(1743)"

Tipi: Şahideli, çatma lahit mezardır.

Ölçü: Baştaşı boy: 143 cm., en: 38 cm., kalınlık: 10 cm., Ayaktaşı boy: 120 cm., en: 34 cm., kalınlık: $12 \mathrm{~cm}$., lahit: $88 \times 240 \mathrm{~cm}$.

Bir kaide üzerine oturtulan baş ve ayak şahideleri bulunan dikdörtgen planl sade lahitin üzeri açıktır. Gövde kısmında bazı tahribatların olduğu görülen, lahitin şahideleri yekparedir.

Baştaşı: Dikdörtgen kesitli düşey dikdörtgen gövdeli baştaşı, sandukadan ayrıldığı kısımda oval bir şekilde daraltılarak devam ettirilmiştir. Şahidenin üzerinde dokuz satırlık sülüs hatı kitabe kuşakları dikdörtgen silmelerle sınırlanan panolar içerisine yazılmıştır. Zeminleri azda olsa hareketlendirilen kabartma yazı kuşakları son üç satırda serbesttir. Sade bezemesi olmayan şahidenin üzerine $17 \mathrm{~cm}$. yükseklikte boyun ve $30 \mathrm{~cm}$. çapında sarıklı bir serpuş yerleştirilmiştir.

Ayaktaşı: Baştaşı ile aynı formda biçimlenen ayaktaşı üstte doğru daralarak devam ettirilmiş ve sivri formda sonlanmıştır. Ayaktaşı sadedir.

\section{Mezar Taşı No: 14}

\section{Fotoğraf No: 14}

Kitabesi: “Tevekkel Telmi' Tilavet-i Kur'an Riza-i Rahman ve ...? Sevdi Dar-ı Dünyada Ta nıy... ruhiyçün

(El Fatiha) (Sene 1154)/(1742)

Tipi: Şahideli, toprak mezardır.

Ölçü: Baştaşı boy: 115 cm., en: 25-30 cm., kalınlık: 25 cm., Ayaktaşı boy: 135 cm., en: 63-24 cm., kalınlık: $20 \mathrm{~cm}$.

Baştaşı: Yekpare olarak ele alınan baştaşının kareye yakın dikdörtgen biçimli alt bölüm üst kısımda üçgen pahlarla ayrılmış ve şahidenin gövdesi üzerine silmelerle sınırlanan dikdörtgen formlu bir kitabelik yerleştirilmiştir. Diğer şahidelerden farklı olarak beş satırlık sülüs karakterli kitabe, gövde kısmından pano şeklinde ayrılarak vurgulan- 
mıştır. Baştaşının üzerine de $13 \mathrm{~cm}$. yükseklikte boyun ve $45 \mathrm{~cm}$. çapında kavuklu bir serpuş yerleştirilmiştir.

Ayaktaşı: Kaide kısmında baştaşı ile aynı özellikte ele alınan ayaktaşının gövdesi çokgen formlu sütun şeklindedir. Ayaktaşı sadedir.

Mezar Taşı No: 15

Fotoğraf No: 15

Kitabesi: “Aşıp Ecreıyn ..?Kem tauna Gelip Ferman

Otağ Eyleyip Şu Muhammed Hafiz el-Kur'an

Oku Bir Fatiha Ruhuna Bu Yatana ihvan

Görüp Firdevs Ulema Bir Halil Oğlu Bu Yatan

Fi zel”

Sene 1251/(1835)

Tipi: Şahideli toprak mezardır.

Ölçü: Baştaşı boy: 100 cm., en: 31 cm., kalınlık: $19 \mathrm{~cm}$.

Baştaşı: Yekpare olarak ele alınan baştaşının kareye yakın dikdörtgen biçimli alt bölüm üst kısımda üçgen pahlarla ayrılmış ve şahidenin gövdesi üzerine silmelerle sınırlanan dikdörtgen formlu bir kitabelik yerleştirilmiştir. Diğer şahidelerden farklı olarak sülüs karakterli altı satırlık kitabe, gövde kısmından pano şeklinde ayrılarak vurgulanmış ve tarih ibaresinin olduğu son satır üç dilimli kemerle sonlanmıştır. Baştaşının üzerine de $22 \mathrm{~cm}$. yükseklikte boyun ve $45 \mathrm{~cm}$. çapında kavuklu bir serpuş yerleştirilmiştir

Ayaktaşı: Ayaktaşı mevcut değildir.

Mezar Taşı No: 16

Fotoğraf No: 16

Kitabesi: "Merhum El Hacı

Sani Efendi

Ruhiyçün

El Fatiha

Sene 128 ?"

Tipi: Şahideli, çatma lahit mezardır.

Ölçü: Baştaşı boy: 104 cm., en: 35-66 cm., kalınlık: 14 cm., Ayaktaşı boy:100 cm., en:35 cm., kalınlık: $14 \mathrm{~cm}$., lahit: 73×213 cm.

Bir kaide üzerine oturtulan baş ve ayak şahideleri bulunan dikdörtgen planlı sade lahitin üzeri açıktır. Küfeki taşla yapılan lahitin şahideleri yekparedir.

Baştaşı: Yekpare olarak ele alınan baştaşının kareye yakın dikdörtgen biçimli alt bölüm üst kısımda üçgen şeklinde pahlanarak devam ettirilmiş ve dikdörtgen kesitli düşey dikdörtgen gövdeli olarak tamamlanmıştır. Baş taşının üzerine beş satırlık sülüs hatlı kitabe yazılmıştır. Kitabeyi oluşturan satırlar yatay dikdörtgen panolarla çerçevelenmiş ve yazılar kabartma olarak verilmiştir. Tarih ibaresinin bulunduğu son satır diğer 
satırlara göre daha geniş tutulmuştur. Sade tutulan şahidenin üstünde $10 \mathrm{~cm}$. yükseklikte boyun ve üzerine de $40 \mathrm{~cm}$. çapında sarıklı bir serpuş yerleştirilmiştir.

Ayaktaşı: Baştaşı ile aynı formda biçimlenen ayaktaşı üstte doğru daralarak devam ettirilmiş ve sivri formda sonlanmıştır. Ayaktaşı sadedir.

Mezar Taşı No: 17

Fotoğraf No: 17

Kitabesi: Hüve'l Hallaku'l Baki

Merhume Tüccar Zade

Mehmed Ağa Kerimesi

Şerife Hanım

Ruhiyçün Fatiha

Sene 1332/(1913)"

Tipi: Şahideli, çerçeveli toprak mezardır.

Ölçü: Baştaşı boy: 135 cm., en: 40 cm., kalınlık: 15 cm., Ayaktaşı boy: 130 cm., en: 35 cm., kalınlık: $21 \mathrm{~cm}$.

Baştaşı: Yekpare olarak ele alınan baştaşının kareye yakın dikdörtgen biçimli alt bölüm üst kısımda pahlanarak devam ettirilmiş ve dikdörtgen kesitli düşey dikdörtgen gövdeli olarak tamamlanmıştır. Şahidenin yukarı doğru genişleyen gövdesi üzerinde altı satırlık sülüs hatlı kitabe, dikdörtgen panolara kabartma olarak yazılmıştır. Tarih ibaresinin olduğu son satır ise oval olarak ele alınmıştır. Baştaşının üstünde geniş tutulan boyun ve onunda üzerine $55 \mathrm{~cm}$. çapında hotoz bir başlık yerleştirilmiştir.

Ayaktaşı: Baştaşı ile aynı formda ele alınan ayaktaşı yekpare ve sadedir. Şahide üst kısımda sivri olarak tamamlanmıştır.

Mezar Taşı No: 18

Fotoğraf No: 18

Kitabesi: ‘Hüve'l Hallaku’l Baki

Si Fatıma Ruhu Koca Beyin Kerime

$\mathrm{Na}$ El Fatiha

Sene 1236/(1820)"

Tipi: Şahideli, çatma lahit mezardır.

Ölçü: Baştaşı boy: 160 cm., en: 63-35 cm., kalınlık: 21 cm., Ayaktaşı boy: 155 cm., en: $25 \mathrm{~cm} .$, kalınlık: $16 \mathrm{~cm}$., lahit: 104×227 cm.

Bir kaide üzerine yerleştirilmiş baş ve ayak şahideleri bulunan dikdörtgen biçimli lahit sade düzenlemeli ve üzeri açıktır.

Baştaşı: Yekpare olarak ele alınan baştaşının kareye yakın dikdörtgen biçimli alt bölüm üste doğru pahlanarak ayrılmış ve gövde dikdörtgen formlu olarak şekillenmiştir. En üstte sivri olarak tamamlanan şahidenin üzerinde sülüs hatla yazılan beş satırlık kitabe kabartma şeklindedir. Kitabe, dikdörtgen biçimli silmelerle çerçevelendirilmiş 
satırlar halinde yazılmıştır. Baştaşının üzerine de $10 \mathrm{~cm}$. yükseklikte boyun ve $25 \mathrm{~cm}$. çapında hotoz bir başlık yerleştirilmiştir.

Ayaktaşı: Baştaşı ile aynı formda biçimlenen sade ayaktaşı üstte doğru daralarak devam ettirilmiştir.

Mezar Taşı No: 19

Fotoğraf No: 19

Kitabesi: 'Hüve'l Hallaku'l Baki

Merhum ve Mağfur Leh

Süleyman Daî Zade

El Hacı Raşid Süleyman

Sene $1277 /(1860)$ "

Ağa Ruhiyçün El Fatiha

Tipi: Şahideli, toprak mezardır.

Ölçü: Baştaşı boy: 120 cm., en: 35 cm., kalınlık: 13 cm., Ayaktaşı boy: 120 cm., en: 36 cm., kalınlık: $10 \mathrm{~cm}$., lahit: ?x225 cm.

Baştaşı: Kaide kısmı tamamen toprağa gömülü olan baştaşı, dikdörtgen kesitli düşey dikdörtgen gövdeli olarak ele alınmıştır. Baş taşının üzerinde sülüs hatla yazılan altı satırlık kitabe, kabartma şeklinde yazılmıştır. Kitabeyi oluşturan satırlar yatay dikdörtgen formlu, içleri pahlarla hareketlendirilen panolarla çerçevelenmiştir. ilk satır ve tarih ibaresinin olduğu son satır serlevha şeklinde düzenlenmiştir. Baştaşının üzerine de $15 \mathrm{~cm}$. yükseklikte boyun ve $36 \mathrm{~cm}$. çapında kavuklu bir başlık yerleştirilmiştir.

Ayaktaşı: Baştaşı ile aynı formda ele alınan ayaktaşı tamamen sadedir.

Mezar Taşı No: 20

Fotoğraf No: 20

Kitabesi: "Merhum ve Mağfur Leh

Sarımsaklı Hafiz

Efendi Ruhiyçün El Fatiha

Sene 1291/(1874)"

Tipi: Şahideli, toprak mezardır.

Ölçü: Baştaşı boy: 115 cm., en: 40 cm., kalınlık: 15 cm., Ayaktaşı boy: 90 cm., en: 36 cm., kalınlık: $17 \mathrm{~cm}$.

Baştaşı: Kaidesi toprağa gömülü olan baştaşı, dikdörtgen biçimli, düşey dikdörtgen gövdeli ve keskin hatlarla tamamlanmıştır. Baştaşının üzerinde dört satırlık sülüs hatla yazılan kitabe yer almaktadır. Kitabeyi oluşturan satırlar yatay dikdörtgen panolarla çerçevelenmiş ve yazılar kabartma olarak yazılmıştır. Tarih ibaresinin olduğu son satır ters yerleştirilen sivri bir kemerle sonlanmıştır. Baştaşının üzerine de $15 \mathrm{~cm}$. yükseklikte boyun ve $30 \mathrm{~cm}$. çapında sarıklı bir serpuş yerleştirilmiştir.

Ayaktaşı: Baştaşı ile aynı formdaki ayaktaşı yekpare ve üstte sivri kemer şeklinde sonlanmış ve sadedir. 
Mezar Taşı No: 21

Fotoğraf No: 21

Kitabesi: "Asiye Hanife

Ve Fatıma kadın

Hanımların

Ruhlarıyçün

El Fatiha

Sene (..taş erimiş)

Tipi: Şahideli toprak mezardır.

Ölçü: Baştaşı boy: 135 cm., en: 38 cm., kalınlık: $20 \mathrm{~cm}$.

Baştaşı: Yekpare olarak ele alınan baştaşının kareye yakın dikdörtgen biçimli alt bölüm üst kısımda köşeleri pahlanarak ayrılmıș ve gövde dikdörtgen biçimli olarak şekillenmiştir. Baştaşının üzerine altı satırlık sülüs hatlı kitabe kuşakları kabartma olarak yazılmıştır. Kitabe, dikdörtgen biçimli silmelerle çerçevelendirilmiş satırlar halinde yazılmıştır. Tarih ibaresinin olduğu son satır oval olarak tamamlanmıştır. Baştaşının üzerine $16 \mathrm{~cm}$. yükseklikte boyun ve $25 \mathrm{~cm}$. çapında hotoz bir başlık yerleştirilmiştir.

Ayaktaşı: Ayaktaşı mevcut değildir.

\section{Mezar Taşı No: 22}

Fotoğraf No: 22

Kitabesi: 'Hüvel'l-Hallaku’l Baki

Bölükbaşı Zade

Es-Seyyid ismail

Ağa Ruhiyçün

El Fatiha Sene 1215/(1801)"

Tipi: Şahideli, çatma lahit mezardır.

Ölçü: Baştaşı boy: 145 cm., en: 47-37 cm., kalınlık: 15cm., Ayaktaşı boy: $130 \mathrm{~cm}$., en: $35 \mathrm{~cm} .$, kalınlık: $17 \mathrm{~cm}$., lahit: $72 \times 225 \mathrm{~cm}$.

Bir kaide üzerine oturtulan baş ve ayak şahideleri bulunan çatma lahitin üzeri açıktır. Gövde kısmında tahribat bulunan lahitin tüm yüzeyi farklı derinlikte tutulan silmelerle çerçevelenmiştir. Baş ve ayaktaşının alt kısımları, dairesel motiflerle hareketlendirilmiştir.

Baştaşı: Yekpare olarak ele alınan baştaşının kareye yakın dikdörtgen biçimli alt bölüm üst kısımda köşeleri kademeli pahlarla ayrılmış, gövde dikdörtgen formlu üstte ise genişleyerek oval olarak şekillenmiştir. Baştaşının üzerinde beş satırlık sülüs hatlı kitabe kabartma olarak yazılmıştır. Kitabe kuşakları düz silmelerle ayrılan köşeleri pahlanarak hareketlendirilen panolarla çerçevelenmiştir. Sade bir düzenlemeye sahip olan baştaşının üzerinde $15 \mathrm{~cm}$. yükseklikte boyun ve $45 \mathrm{~cm}$. çapında çubuklu taşkın sarıklı bir kavuk yerleştirilmiştir. 
Ayaktaşı: Baştaşı ile aynı formda biçimlenen ayaktaşı üstte doğru daralarak devam ettirilmiş ve sivri kemer şeklinde sonlanmıştır. Ayaktaşı sadedir.

Mezar Taşı No: 23

Fotoğraf No: 23

Kitabesi: “Hüvel'l-Hallaku'l Baki

Merhum ve Mağfur

Kâtip Zade Mustafa Ağa

Ruhiyçün El Fatiha

Sene $1298 /(1880) "$

Tipi: Şahideli, toprak mezardır.

Ölçü: Baştaşı boy: 155 cm., en: 38-64 cm., kalınlık: 25 cm., Ayaktaşı boy: 152 cm., en: 37 cm., kalınlık: $17 \mathrm{~cm}$.

Baştaşı: Yekpare olarak ele alınan baştaşının kareye yakın dikdörtgen biçimli alt bölüm köşeleri pahlanarak gövdeden ayrılan baştaşı, dikdörtgen biçimli olarak devam ettirilmiştir. Keskin hatlarla tamamlanan baştaşının gövdesinde beş satırlık sülüs hatlı kitabe, kabartma olarak yazılmıştır. Kaide kısmında daha geniş olan bu kuşaklar düz silmelerle ayrılan dikdörtgen panolarla çerçevelenmiştir. Alt tarih ibaresinin olduğu satır diğerlerine göre daha geniş tutulmuş ve yarım yuvarlak formludur. Baştaşının üzerine de $20 \mathrm{~cm}$. yükseklikte boyun ve $30 \mathrm{~cm}$. çapında kavuklu bir başlık yerleştirilmiştir.

Ayaktaşı: Baştaşı ile aynı formda biçimlenen ayaktaşı üstte daralarak devam ettirilmiştir. Ayaktaşı sadedir.

\title{
Mezar Taşı No: 24
}

Fotoğraf No: 24

Kitabesi:

\author{
“Hüve'l Hallaku'l Baki \\ Toklu Zade Osman \\ Kerimesi Havva Ruhiyçün \\ El Fatiha \\ Sene 1215/(1801)"
}

Tipi: Şahideli, toprak mezardır.

Ölçü: Baştaşı boy: 100 cm., en: 35 cm., kalınlık: 14 cm., Ayaktaşı boy: 85 cm., en: 36 cm., kalınlık: 14 cm.

Baştaşı: Kaidesi toprağa gömülü olan baştaşı, üçgen pahlarla ayrılarak gövde dikdörtgen formlu olarak devam ettirilmiş ve üstte oval olarak tamamlanmıştır. Baştaşının üzerinde tüm yüzeyini kaplayacak şekilde dört satırlık sülüs hatlı kitabe, kabartma olarak yazılmıştır. Kitabe, geniş aralıklarla sıralanmış ve düz silmelerle ayrılan panolarla çerçevelenmiştir. Sade olan baştaşının üzerinde $14 \mathrm{~cm}$. yükseklikteki boyun ve $26 \mathrm{~cm}$. çapında hotoz bir başlık yerleştirilmiştir. sadedir.

Ayaktaşı: Büyük bir kısmı toprağa gömülü olan ayaktaşı, dikdörtgen formlu ve 
Mezar Taşı No: 25

Fotoğraf No: 25

Kitabesi: Edip Rıhlet Şahadet Dünyadan

Ki Toklu Zade Osman Ağanın Ziyaretten Arz En Çok Duadır Oku Bir Fatiha Ey Hayır Ola Nam De Talebi ...?derli An'a Ruhunu Kılar Mihman Bahşet Beni de Mevla'm"

Tipi: Şahideli, toprak mezardır.

Ölçü: Baştaşı boy: 110 cm., en: 36 cm., kalınlık: 18 cm., Ayaktaşı boy: 112 cm., en: 38 cm., kalınlık: $20 \mathrm{~cm}$.

Baştaşı: Kaidesinin tamamı toprağa gömülü olan baştaşının, gövdeye geçişi keskin üçgen pahlarla sağlanmıştır. Kaideden sonra dikdörtgen biçimli olarak devam ettirilen şahide üstte oval olarak tamamlanmıştır. Baştaşının gövdesi ve kaidenin belli bir kısmını kaplayan kitabe sülüs hatla altı satır halinde yazılmıştır. Yazılar, kabartma olarak verilmiş, düzenli sıralanan kitabe, silmelerle ayrılan panolarla çerçevelenmiştir. Sade bir düzenlemeye sahip olan baştaşının üzerinde $12 \mathrm{~cm}$. yükseklikte boyun ve $50 \mathrm{~cm}$. çapında sarıklı bir başlık yerleştirilmiştir.

Ayaktaşı: Ayaktaşı, dikdörtgen formlu ve oldukça sadedir.

\section{Mezar Taşı No: 26}

Fotoğraf No: 26

Kitabesi: 'Hüvel'l-Hallaku'l Baki

Nuş Edüb Mevtin Şarabını Eyle.

Ya İlahi Eyler misin ..Kulunu Her Demde Şad

Rahmetin Dünyasına Arif Eyle An'ı Ya Latif

Evvela Habibin Hürmetine Ver Ona Cennet Ziyade

Fatiha (Ana) Her Çare Eyle Lütuf Edip

Şefaat Olup Şefaat Eylesin Bu ...?

Görmeyip Dünya Muradı ve Aldı Beni Neylesin

Razı Olup Ahır Hakka Alada Diler İnkıyada

Tabi Bu Fatiha'nın Söylersen Tarihini

Okuyup Bir Fatiha Ruhuna Eyle Ona Dua

Sene $1213 /(1798) "$

Tipi: Şahideli, toprak mezardır.

Ölçü: Baştaşı boy: 144 cm., en: 44 cm., kalınlık: 18 cm., Ayaktaşı boy: 140 cm., en: 40 cm., kalınlık: $18 \mathrm{~cm}$.

Baştaşı: Yekpare olarak ele alınan baştaşının kareye yakın dikdörtgen biçimli alt bölüm köşeleri kademeli pahlarla ayrılmış ve gövde altta dikdörtgen formlu üstte ise genişleyerek tamamlanmıştır. Baştaşının üzerinde on iki satırlık sülüs hatlı kitabe, kabartma olarak yazılmıştır. Kitabe düz silmelerle ayrılarak hareketli panolarla çerçeve- 
lenmiştir. Sade olan baştaşının üzerine $22 \mathrm{~cm}$. yükseklikteki boyun ve $35 \mathrm{~cm}$. çapında hotoz bir başlık yerleştirilmiştir.

Ayaktaşı: Baştaşı ile aynı formda biçimlenen ayaktaşı üstte doğru daralarak devam ettirilmiş ve sivri olarak sonlanmıştır. Ayaktaşı sadedir.

Mezar Taşı No: 27

Fotoğraf No: 27

Kitabesi: "Merhum ve Mağfur

Tüccar Zade ibrahim Ağa

Oğlu Nuri Ağa

Oku Bir Fatiha

ihlâs Sahibi Kerim

Sene $1121 /(1709) "$

Tipi: Şahideli, çerçeveli toprak mezardır.

Ölçü: Baştaşı boy: 140 cm., en: 36 cm., kalınlık: $9 \mathrm{~cm}$.

Baştaşı: Yekpare olarak ele alınan baştaşının kareye yakın dikdörtgen biçimli alt bölüm üste doğru pahlanarak devam ettirilmiş ve şahide dikdörtgen kesitli düşey dikdörtgen gövdeli olarak tamamlanmıştır. Baş taşının üzerinde altı satırlık sülüs hatlı kitabe yazılmıştır. Kitabeyi oluşturan satırlar dikdörtgen panolarla çerçevelenmiş ve yazılar kabartma olarak verilmiştir. Tarih ibaresinin olduğu son satır diğer satırlardan daha geniş tutulmuştur. Şahidenin üzerine de yüksek bir boyun ve $100 \mathrm{~cm}$. çapında kavuklu bir serpuş yerleştirilmiştir.

Ayaktaşı: Ayaktaşı baştaşı ile aynı formda ve sadedir.

\section{Mezar Taşı No: 28}

Fotoğraf No: 28

Kitabesi: “Hüve'l Hallaku'l Baki

Merhum ve Mağfurun Leh

Katib Zade Mehmed Ağanın

Ruhiyçün El Fatiha"

Tipi: Şahideli, toprak mezardır.

Ölçü: Baştaşı boy: 140 cm., en: 40 cm., kalınlık: 9 cm., Ayaktaşı boy: 125 cm., en: 37 cm., kalınlık: $17 \mathrm{~cm}$.

Baştaşı: Yekpare olarak ele alınan baştaşının kareye yakın dikdörtgen biçimli alt bölüm üstte keskin bir pahla kesilerek devam ettirilmiş ve şahide, dikdörtgen kesitli düşey dikdörtgen gövdeli olarak tamamlanmıştır. Baştaşının üzerinde dört satırlık sülüs hatlı kitabe, kabartma şeklinde yazılmışır. Kitabe düz silmelerle ayrılan dikdörtgen panolarla çerçevelenmiştir. Sade düzenlenen baştaşının üzerine de geniş bir boyun ve 70 cm. çapında kavuklu bir başlık yerleştirilmiştir.

Ayaktaşı: Baştaşı ile aynı formda ele alınan ayaktaşı yekpare ve sadedir. Üst kısımda ise sivri olarak tamamlanmıştır. 
Mezar Taşı No: 29

Fotoğraf No: 29

Kitabesi:

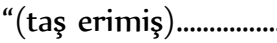 \\ Si Ali \\ Ehli \\ Tuti Hanım Ruhiyçün \\ El Fatiha \\ Sene 1282/(1865)"
}

Tipi: Şahideli, toprak mezardır.

Ölçü: Baştaşı boy: 120 cm., en: 27 cm., kalınlık: 12 cm., Ayaktaşı boy: 130 cm., en: 28 cm., kalınlık: $12 \mathrm{~cm}$.

Baştaşı: Yekpare baştaşı yarıya kadar toprağa gömülü haldedir. Şahide, kaideden üste doğru oval olarak pahlanmış ve dikdörtgen kesitli düşey dikdörtgen gövdeli olarak tamamlanmıştır. Baştaşının üzerinde kalan izlerden anlaşıldığı kadarıyla yedi satırlık sülüs hatlı kitabe yazılmıştır. Kitabeyi oluşturan satırlar yatay dikdörtgen panolarla çerçevelenmiş ve yazılar kabartma şeklinde verilmiştir. Tarih ibaresinin bulunduğu son satır diğer satırlara göre daha geniş olup yuvarlak bir kemerle sonlanmıştır. Şahidenin üzerinde son üç satır sağlam olup ilk satırlarda taş tamamen erimiştir. Sade bir düzenlemeye sahip olan baştaşının üzerine de bir boyun ve $65 \mathrm{~cm}$. çapında hotoz bir başlık yerleştirilmiştir.

Ayaktaşı: Baştaşı ile aynı formda ele alınan ayaktaşı üstte sivri bir kemerle şekillenmiştir. Şahidenin üzerinde stilize edilmiş bir selvi motifi işlenmiştir. Bir kaide üzerine oturtulan selvi tüm yüzeyi kaplayacak şekilde yerleştirilmiş ve üstte farklı olarak sonlanmıştır. Gövdeden iki bölüme ayrılan ağaç yukarı doğru daralarak tamamlanmış ve burada yanlara çıkan yapraklar üstte bir palmetle sonlanmıştır. Üstteki bu yaprak ve palmet diştan damla şeklinde bir çerçeve ile sınırlanmıştır.

\title{
Mezar Taşı No: 30
}

Fotoğraf No: 30

Kitabesi: "Merhum ve Mağfur

Celil Ağanın Kerimesi

Hanife Hatun Ruhıç̧ün El Fatiha

Sene 1253/(1837)"

Tipi: Şahideli, toprak mezardır.

Ölçü: Baştaşı boy: 138 cm., en: 35 cm., kalınlık: 14 cm.

Baştaşı: Yekpare olarak ele alınan baştaşının kareye yakın dikdörtgen biçimli alt bölüm üst kısımda oval olarak pahlanarak devam ettirilmiş ve şahide dikdörtgen kesitli düşey dikdörtgen gövdeli olarak tamamlanmıştır. Şahidenin gövdesinde dört satırlık sülüs hatlı kitabe, kabartma şeklinde yazılmıştır. Kitabe satırları düz silmelerle ayrılarak dikdörtgen panolarla çerçevelenmiştir. Sade düzenlenen baştaşı üstte sivri bir kemerle hareketlendirilmiş ve bu bölüm kısmen tahrip olmuştur.

Ayaktaşı: Ayaktaşı mevcut değildir. 
Mezar Taşı No: 31

Fotoğraf No: 31

Kitabesi: $\quad$ “Hüve'l Hallaku’l Baki

Merhum ve Mağfur Sebih Ağa

Nın Validesi Fatıma

Hatun Ruhıyçün

El Fatiha

Sene $1177 /(1820) "$

Tipi: Şahideli, toprak mezardır.

Ölçü: Baştaşı boy: 115 cm., en: 31 cm., kalınlık: 10 cm., Ayaktaşı: 110 cm., en:27 cm., kalınlık: $10 \mathrm{~cm}$.

Baştaşı: Yekpare olarak ele alınan baştaşının kareye yakın dikdörtgen biçimli alt bölüm üst kısımda keskin bir pahla kesilerek devam ettirilmiş ve dikdörtgen kesitli düşey dikdörtgen gövdeli olarak tamamlanmıştır. Altı satırlık kitabe, yuvarlak kemerli ve fazla derin olmayan bir pano içerisine yerleştirilmiştir. Talik hatlı kitabe, kabartma şeklinde ve serbest olarak yazılmıştır. Şahidenin yüzeyi kitabe dışında işlenmemiş, üstte yuvarlak formda sonlanan başlıkta da bitmemişlik söz konusudur.

Ayaktaşı: Baştaşı ile aynı formda ele alınan ayaktaşı yekpare ve sadedir. Üst kısımda ise sivri olarak tamamlanmıştır.

Mezar Taşı No: 32

Fotoğraf No: 32

Kitabesi: "Hacı Osman Efendinin

Kerimesi Şerife Aliş Hatun

Ruhıçün Fatiha

Sene 1183/(1769)

Fi 11 Şevval"

Tipi: Şahideli, çatma lahit mezardır.

Ölçü: Baştaşı boy: 203 cm., en: 48-35-90 cm., kalınlık: $12 \mathrm{~cm}$.

Şahideli, çatma lahit sade olup dağılmış haldedir.

Baştaşı: Yekpare olarak ele alınan baştaşının kareye yakın dikdörtgen biçimli alt bölüm üst kısma doğru keskin bir üçgen pahla kesilerek devam ettirilmiş ve şahide dikdörtgen kesitli düşey dikdörtgen gövdeli olarak tamamlanmıştır. En üstte üçgen şeklinde sonlanan baştaşının yüzeyi kitabe dışında işlenmemiştir. Köşeleri yumuşatılmış yatay dikdörtgen formlu niş şeklindeki kitabe, serbest olarak dört satır halinde yazılmıştır.

Ayaktaşı: Ayaktaşı, baştaşı ile aynı formda ele alınmış fakat parçalanmış durumdadır. 
Mezar Taşı No: 33

Fotoğraf No: 33

Kitabesi:

\author{
"Fatıma Hatun \\ Ruhıyçün \\ Elfatiha \\ Sene 1181/(1767) Ramazan" \\ "Fatıma Hatun \\ Ruhıyçün \\ Elfatiha \\ Sene 1181/(1767) Ramazan"
}

Tipi: Şahideli, çatma lahit mezardır.

Ölçü: Baştaşı boy: 116 cm., en: 39 cm., kalınlık: 14 cm., Ayaktaşı boy: 130 cm., en: 38 cm., kalınlık: $13 \mathrm{~cm}$., lahit: ?.

Şahideli, çatma lahit sade olup dağılmış haldedir.

Baştaşı: Yekpare baştaşının kaide kısmı tamamen toprağa gömülmüş vaziyettedir. Dikdörtgen kesitli düşey dikdörtgen gövdeli olarak devam eden baştaşı üst kısımda sivri bir kemerle sonlanmıştır. Şahidenin gövde yüzeyinde alt ve üst kısımda pano şeklinde ele alınan yatay dikdörtgen formlu iki kitabeliye yer verilmiştir. Köşeleri içten pahlanan kitabe sülüs hatla serbest olarak dört satır halinde yazılmıştır. Benzer özellikte ele alınan bu kitabelerin içerisindeki yazılarda da aynıdır.

Ayaktaşı: Baştaşı ile aynı formda ele alınan ayaktaşı yekpare ve sadedir.

\title{
Mezar Taşı No: 34
}

Fotoğraf No: 34

Kitabesi: "Seyyid Hasan Ağanın

Oğlu Seyyid Hüseyin

Ağa Ruhıyçün El Fatiha

Sene 1206/(1791)"

Tipi: Şahideli, çatma lahit mezardır.

Ölçü: Baştaşı boy: 110 cm., en: 33 cm., kalınlık: 13 cm., Ayaktaşı boy: 110 cm., en: 32 cm., kalınlık: $11 \mathrm{~cm}$., lahit: 70x235 cm.

Şahideleri bulunan dikdörtgen formlu çatma lahit sade olup üzeri açıktır.

Baştaşı: Yekpare olarak ele alınan baştaşının kareye yakın dikdörtgen biçimli alt bölüm üst kısımda keskin üçgen pahlarla ayrılarak gövde kısmında kare bir kitabelik oluşturulmuştur. Alt ve üst kısımlarda oval olarak kesilen gövde, dıştan bir silme ile sınırlanmıştır. Şahidenin üzerinde dört satırlık sülüs hatlı kitabe, kabartma şeklinde yazılmıştır. Kitabe, düz silmelerle ayrılmış içten pahlarla hareketlendirilen dikdörtgen panolarla çerçevelenmiştir. Tarih ibaresinin olduğu son satır yuvarlak formlu düzenlemiştir. Sade baştaşının üzerine de geniş bir boyun ve $93 \mathrm{~cm}$. çapında kavuklu bir başlık yerleştirilmiştir. 
Ayaktaşı: Baştaşı ile aynı formda ele alınan ayaktaşı yekpare ve sadedir. Üst kısımda ise sivri olarak tamamlanmıştır.

\section{Mezar Taşı No: 35}

Fotoğraf No: 35

Kitabesi: "Hasır Zade ibrahim Ağa Kerimesi Şerife Fatıma Ruhıyçün El Fatiha Sene 1202/(1787)"

Tipi: Şahideli, toprak mezardır.

Ölçü: Baştaşı boy: 147 cm., en: 34 cm., kalınlık: 13 cm., Ayaktaşı boy: 125 cm., en: 35 cm., kalınlık: $14 \mathrm{~cm}$.

Baştaşı: Yekpare olarak ele alınan baştaşının kareye yakın dikdörtgen biçimli alt bölüm üst kısımda keskin bir pahla kesilerek devam ettirilmiş ve şahide dikdörtgen kesitli düşey dikdörtgen gövdeli olarak tamamlanmıştır. Gövdenin üzerinde yuvarlak kemerle şekillenen kitabeliğe yer verilmiştir. Düz olarak beş satırlık sülüs hatlı yazı kabartma olarak yazılmıştır. Tarih ibaresinin olduğu satır kartuş şeklinde düzenlenirken duanın olduğu satır da yanlardan yumuşatılmıştır. Şahidenin yüzeyi kitabe dışında sade olup üstte yuvarlak formda sonlanmıştır. Başlıkta bir yarım kalmış olma ihtimali söz konusudur.

Ayaktaşı: Baştaşı ile aynı formda ele alınan ayaktaşı yekpare ve sadedir. Üst kısımda ise sivri olarak tamamlanmıştır.

Mezar Taşı No: 36

Fotoğraf No: 36

Kitabesi: 'Hüvel Hallaku’l Baki

Merhum ...dar Efendi

Ehli Hatice Akkadın

Ruhiyçün El Fatiha

Sene 1243/(1827)"

Tipi: Şahideli, çatma lahit mezardır.

Ölçü: Baştaşı boy:120 cm., en: 36 cm., kalınlık: 16 cm., Ayaktaşı: kırık., lahit: 70x216 $\mathrm{cm}$.

Şahideleri bulunan dikdörtgen planlı çatma lahit sade olup üzeri açıktır.

Baştaşı: Yekpare olarak ele alınan baştaşının kareye yakın dikdörtgen biçimli alt bölüm üst kısımda keskin bir pahla kesilerek devam ettirilmiş ve şahide dikdörtgen kesitli düşey dikdörtgen gövdeli olarak tamamlanmıştır. Şahidenin üzerinde dört satırlık sülüs hatlı kitabe, kabartma şeklinde yazılmıştır. Kitabe düz silmelerle ayrılarak içten pahlarla hareketlendirilen dikdörtgen panolarla çerçevelenmiştir. Tarih ibaresinin olduğu son satır yuvarlak formlu düzenlenmiştir. 
Ayaktaşı: Çatma lahit üzerinde ayaktaşının sadece kaidesi kalmıştır.

\author{
Mezar Taşı No: 37
}

Fotoğraf No: 37

Kitabesi: "Sene 1262/(1845)

Hüv'el Hallaku'l Baki

Merhum ve Mağfur Leha

Merhum Tahir Ağa

Kerimesi Fatıma

Pembe Hanım Ruhıyçün

Tahir Ağa Zevcesi

Ağca Hanım Ruhıyçün Fatiha

Sene...."

Tipi: Şahideli, toprak mezardır.

Ölçü: Baştaşı boy: 142 cm., en: 26-35 cm., kalınlık: 10 cm., Ayaktaşı boy: 156 cm., en: $31 \mathrm{~cm} .$, kalınlık: $13 \mathrm{~cm}$.

Baştaşı: Yekpare olarak ele alınan baştaşının kareye yakın dikdörtgen biçimli alt bölüm üst kısımda pahlanarak devam ettirilmiş ve şahide dikdörtgen kesitli düşey dikdörtgen gövdeli olarak tamamlanmıştır. Şahide üstte genişleyerek sivri bir şekilde sonlanırken üzeri yazı kuşakları ile dolgulanmıştır. ilk satır yuvarlak bir kartuşla çerçevelenmiş, üstüne bir kır çiçeği yatay olarak yerleştirilmiş, alt kısmada tarihi yazılmıştır. Daha sonra sekiz satırlık sülüs hatlı yazı kabartma şeklinde verilmiştir. Kitabe silmelerle ayrılarak sade dikdörtgen panolarla çerçevelenmiştir. Tarih ibaresinin olduğu son satır kartuş şeklinde düzenlenmiş ve tahrip olmuştur.

Ayaktaşı: Baştaşı ile aynı formda ele alınan ayaktaşı yekpare ve üzerine kök boya ile bir selvi boyanmıştır. Kalan izlerden anlaşıldığı kadarıyla, şahidenin kenarları dilimli bir perde ile sınırlanmış ve tüm yüzey boyunca uzatılan selvinin baş kısmı sağa eğilmiş haldedir.

\title{
Mezar Taşı No: 38
}

Fotoğraf No: 38

Kitabesi: ‘Hüvel Hallaku’l Bakı Merhum El Hacı Ahmed

Ağa Zade Haşim Ağa

Ruhıç̧ün El Fatiha

Sene 1257/(1841)"

Tipi: Şahideli, toprak mezardır.

Ölçü: Baştaşı boy: 115 cm., en: 35 cm., kalınlık: $13 \mathrm{~cm}$.

Baştaşı: Yekpare olarak ele alınan baştaşının kareye yakın dikdörtgen biçimli alt bölüm üst kısımda keskin bir pahla kesilerek şahide dikdörtgen kesitli düşey dikdörtgen gövdeli olarak tamamlanmıştır. Şahidenin üzerinde beş satırlık sülüs hatlı kitabe, kabartma şeklinde yazılmıştır. Kitabe satırları silmelerle ayrılarak dikdörtgen formlu pano- 
larla sınırlanmıştır. Tarih ibaresinin olduğu son satır kartuş şeklinde düzenlenmiştir. Baştaşııın üzerinde yüksek bir boyun ve $72 \mathrm{~cm}$. çapında kavuklu bir başlık yerleştirilmiştir.

Ayaktaşı: Ayaktaşı mevcut değildir.

Mezar Taşı No: 39

Fotoğraf No: 39

Kitabesi: $\quad$ "1250/(1834)

Hüv'el Hallaku'l Baki

Merhum Mustafa Efendinin

Oğlu Mahmud Efendinin

Ruhıyçün El Fatiha"

Tipi: Şahideli, toprak mezardır.

Ölçü: Baştaşı boy: 140 cm., en: 45 cm., kalınlık: 17 cm., Ayaktaşı boy: 125 cm., en: 36 cm., kalınlık: $14 \mathrm{~cm}$.

Baştaşı: Yekpare baştaşının kaide kısmı tamamen toprağa gömülüdür. Dikdörtgen kesitli düşey dikdörtgen gövdeli olarak devam eden şahidenin üzerinde beş satırlık sülüs hatlı kitabe kabartma şeklinde yazılmıştır. Kitabe silmelerle ayrılan içten pahlandırılan hareketli dikdörtgen panolarla çerçevelenmiştir. Üst boyun kısmında sivri kemerlerin birleşmesi ile adeta tek kubbeli bir yapı oluşturulmaya çalışılmıştır. Sade düzenlenen baştaşının üzerine de geniş bir boyun ve $110 \mathrm{~cm}$. çapında kavuklu bir başlık yerleştirilmiştir.

Ayaktaşı: Baştaşı ile aynı formda ele alınan ayaktaşı yekpare ve sadedir. Üst kısımda ise sivri olarak tamamlanmıştır.

\section{Mezar Taşı No: 40}

Fotoğraf No: 40

Kitabesi: 'Hüv'el Hallaku'l Baki

Merhum ve Mağfur

Leh Mahmud Efendi Zade

Mehmed Sadık Efendinin

Ruhıç̧ün El Fatiha

Sene 1272/(1855)"

Tipi: Şahideli, toprak mezardır.

Ölçü: Baştaşı boy: $120 \mathrm{~cm}$., en: $32 \mathrm{~cm}$., kalınlık: $12 \mathrm{~cm}$., lahit: $65 \times 210 \mathrm{~cm}$.

Şahideli, çatma lahit sade olup bir kısmı dağılımış durumdadır.

Baştaşı: Yekpare olarak ele alınan baştaşıın kareye yakın dikdörtgen biçimli alt bölüm üst kısımda keskin bir pahla kesilerek şahide, dikdörtgen kesitli düşey dikdörtgen gövdeli olarak tamamlanmıştır. Şahidenin üzerinde altı satırlık sülüs hatlı kitabe, kabartma şeklinde yazılmıştır. Kitabe, silmelerle ayrılan dikdörtgen panolarla çerçevelenmiş 
tarih ibaresinin olduğu satır yarım yuvarlak bir kartuşla sonlanmıştır. Baştaşının üzerinde yüksek bir boyun ve $105 \mathrm{~cm}$. çapında kavuklu bir başlık yerleştirilmiştir.

Ayaktaşı: Ayaktaşı mevcut değildir.

\section{Mezar Taşı No: 41}

Fotoğraf No: 41

Kitabesi: "Sene 1277/(1860)

Hüv'el Hallaku'l Baki

Merhum ve Mağfur

Leha Haşim Ağa Kerimesi

Molla Hatunun

Ruhıç̧ün

El Fatiha"

Tipi: Şahideli, toprak mezardır.

Ölçü: Baştaşı boy: 165 cm., en: 37 cm., kalınlık: 12 cm., Ayaktaşı boy: 160 cm., en: 34 cm., kalınlık: $11 \mathrm{~cm}$.

Baştaşı: Yekpare baştaşı dikdörtgen kesitli düşey dikdörtgen gövdeli olup üste doğru daralarak sivri bir şekilde sonlanmıştır. Şahidenin üzerinde ilk satır yuvarlak kemerle çerçevelenmiş ve buraya tarih ibaresi yazılmıştır. Daha sonra altı satırlık sülüs hatlı yazı kabartma şeklinde verilmiştir. Kitabe, silmelerle ayrılarak sade dikdörtgen panolarla çerçevelenmiştir. Son satırdan önceki panonun soluna stilize bir yaprak ve kır çiçeği işlenmiştir. Dua ibaresinin olduğu son satır yanlarda sivri kemerle tamamlanan pano şeklinde düzenlenmiştir.

Ayaktaşı: Baştaşı ile aynı formda ele alınan ayaktaşı yekpare ve sadedir.

\section{Mezar Taşı No: 42}

Fotoğraf No: 42

Kitabesi: Merhum El Hacı Kethüda

Zade Süleyman Ağa

Ruhıçün El Fatiha

Sene 1209/(1794)"

Tipi: Şahideli, çatma lahit mezardır.

Ölçü: Baştaşı boy: 120 cm., en: 35 cm., kalınlık: 19 cm., Ayaktaşı boy: 110 cm., en: 30 cm., kalınlık: $10 \mathrm{~cm}$., lahit: 55×222 cm.

Şahideleri bulunan dikdörtgen planlı çatma lahit sade olup üzeri açıktır.

Baştaşı: Yekpare olarak ele alınan baştaşının kareye yakın dikdörtgen formlu kaidesi üst kısımda keskin bir pahla kesilerek dikdörtgen kesitli düşey dikdörtgen gövdeli olarak tamamlanmıştır. Şahidenin üzerinde boyun kısmına yakın yerde dört satırlık sülüs hatlı kitabe, kabartma olarak yazılmıştır. Kitabe, silmelerle ayrılarak sade dikdörtgen panolarla çerçevelenmiştir. Baştaşının üstünde geniş boyun ve onunda üzerinde 93 cm. çapında kavuklu bir başlık yerleştirilmiştir. 
Ayaktaşı: Baştaşı ile aynı formda ele alınan ayaktaşı yekpare ve sadedir. Üst kısımda ise sivri olarak tamamlanmıştır.

\section{Mezar Taşı No: 43}

Fotoğraf No: 43

Kitabesi: "Merhum ve Mağfur Leha Turan Efendi Hafidesi Fatıma Hanım Ruhıçün El Fatiha Sene $1242 /(1826) "$

Tipi: Şahideli, toprak mezardır.

Ölçü: Baştaşı boy: 115 cm., en: 36 cm., kalınlık: 16 cm., Ayaktaşı boy: 132 cm., en: 33 cm., kalınlık: $12 \mathrm{~cm}$.

Baştaşı: Yekpare olarak ele alınan baştaşının kareye yakın dikdörtgen formlu alt bölümü üst kısımda pahlanarak devam ettirilmiştir. Kaideden sonra dikdörtgen kesitli düşey dikdörtgen gövdeli şahide üste doğru genişleyerek dairesel şekilde sonlanmıştır. Şahidenin üzerinde altı satırlık sülüs hatlı kitabe kabartma şeklinde yazılmıştır. Kitabe, silmelerle ayrılan köşeleri yumuşatılan dikdörtgen panolarla çerçevelenmiştir. Tarih ibaresinin olduğu son satır kartuş şeklinde ve sivri kemerle sonlanmıştır. Baştaşının üstünde üzerine takılar takılmış yüksek boyun ve onunda üzerine $73 \mathrm{~cm}$. çapında hotoz bir başlık yerleştirilmiştir.

Ayaktaşı: Baştaşı ile aynı formda ele alınan ayaktaşı yekpare ve sadedir. Üst kısımda ise sivri bir kemerle tamamlanmıştır.

Mezar Taşı No: 44

Fotoğraf No: 44

Kitabesi: "Merhum ve Mağfurun Leh Turan Efendi Gelini Fatıma Hanım Ruhuna Fatiha Sene 1243/(1827)"

Tipi: Şahideli, toprak mezardır.

Ölçü: Baştaşı boy: 110 cm., en: 38 cm., kalınlık: 20 cm., Ayaktaşı boy: 135 cm., en: 32 cm., kalınlık: $12 \mathrm{~cm}$.

Baştaşı: Yekpare olarak ele alınan baştaşının kareye yakın dikdörtgen biçimli alt bölüm üst kısımda pahlanarak devam ettirilmiş ve şahide dikdörtgen kesitli düşey dikdörtgen gövdeli olarak tamamlanmıştır. Oval şekilde genişleyen şahidenin üzerinde dört satırlık sülüs hatlı kitabe, kabartma olarak yazılmıştır. Kitabe silmelerle ayrılarak köşeleri yumuşatılan dikdörtgene yakın panolarla çerçevelenmiştir. Tarih ibaresinin olduğu son satır yanlardan daraltılan dikdörtgen bir kartuşla sonlanmıştır. Baştaşının üstünde üzerine takılar takılmış yüksek boyun ve onunda üzerine $70 \mathrm{~cm}$. çapında hotoz bir başlık yerleştirilmiştir. 
Ayaktaşı: Baştaşı ile aynı formda ele alınan ayaktaşı yekpare ve sadedir. Üst kısımda sivri olarak tamamlanmıştır.

\section{Mezar Taşı No: 45}

Fotoğraf No: 45

Kitabesi:

“Hüvel Hallaku'l Baki

Merhum ve Mağfur Leha

Issmail Kerimesi

Fatıma Ruhıç̧ün

El Fatiha

Ve Kerimesi Ayşe

Sene 1235/(1819)"

Tipi: Şahideli, toprak mezardır.

Ölçü: Baştaşı boy: $125 \mathrm{~cm}$., en: $30 \mathrm{~cm} .$, kalınlık: $8 \mathrm{~cm}$.

Baştaşı: Yekpare olarak ele alınan baştaşının kareye yakın dikdörtgen biçimli alt bölüm üst kısımda keskin bir pahla kesilerek şahide, dikdörtgen kesitli düşey dikdörtgen gövdeli olarak tamamlanmıştır. Şahidenin üzerinde yedi satırlık talik hatı kitabe, kabartma şeklinde yazılmıştır. Kitabe satırları silmelerle ayrılarak sade dikdörtgen panolarla çerçevelenmiştir. Tarih ibaresinin olduğu son satır volütlerle birleştirilen yuvarlak formlu kartuş şeklinde düzenlenmiştir. Baştaşının üstünde yüksek bir boyun ve onunda üzerinde takıların olduğu $52 \mathrm{~cm}$. çapında hotoz bir başlık yerleştirilmiştir.

Ayaktaşı: Ayaktaşı mevcut değildir.

\section{Mezar Taşı No: 46}

Fotoğraf No: 46

Kitabesi: “Hüvel Hallaku’l Baki

Merhum El Hacı Bekir Ağa Zade

El Hacı Ahmed Ağa

Ruhıç̧ün

El Fatiha Sene 1238/(1822)"

Tipi: Şahideli, toprak mezardır.

Ölçü: Baştaşı boy: 105 cm., en: 34 cm., kalınlık: 18 cm., Ayaktaşı boy: 103 cm., en: 31 cm., kalınlık: $18 \mathrm{~cm}$.

Baştaşı: Yekpare olarak ele alınan baştaşının kareye yakın dikdörtgen biçimli alt bölüm üst kısımda keskin bir pahla kesilerek şahide dikdörtgen kesitli düşey dikdörtgen gövdeli ve hafif genişleyerek tamamlanmıştır. Şahidenin üzerinde boyun kısmına yakın yerde beş satırlık sülüs hatlı kitabe, kabartma şeklinde yazılmıştır. Kitabe, silmelerle ayrılarak içten pahlanarak hareketlendirilen dikdörtgen panolarla çerçevelenmiştir. Baştaşının üstünde kısa bir boyun ve onunda üzerinde $110 \mathrm{~cm}$. çapında kavuklu bir başlık yerleştirilmiştir.

Ayaktaşı: Baştaşı ile aynı formda ele alınan ayaktaşı yekpare ve sadedir. Üst kısımda sivri bir olarak tamamlanmıştır. 


\section{Mezar Taşı No: 47}

Fotoğraf No: 47

Kitabesi: Yok.

Tipi: Şahideli, çatma lahit mezardır.

Ölçü: Baştaşı boy: 142 cm., en: 35-26 cm., kalınlık: 10 cm., Ayaktaşı boy: 156 cm., en: $31 \mathrm{~cm} .$, kalınlık: $13 \mathrm{~cm}$.

Baştaşı: Yekpare baştaşının kaide kısmı tamamen toprağa gömülü haldedir. Dikdörtgen kesitli düşey dikdörtgen planlı şahidenin gövdesinde, kaidesi olan bir selvi motifi işlenmiştir. Üste doğru daralan selvi başı sağa doğru eğilmiş vaziyettedir. Baştaşı üstte dilimli olarak sonlanmıştır.

Ayaktaşı: Baştaşı ile aynı formda ele alınan ayaktaşı yekpare ve sadedir.

\section{Değerlendirme}

Bu çalışmada, Gesi Mezarlığında (Foto.48) bulunan tarihi mezar taşları konu olarak alınmıştır. Mezarlıktaki tüm örnekler incelenmekle birlikte bilimsel anlamda fikir verecek farklı tiplerde 47 mezar şahideleri ve lahitleri ile detaylı bir şekilde incelenerek tanıtılmış ve kitabeleri okunmuştur. Mezarlık içerisinde yer alan mezartaşları; tip, malzeme, teknik ve bezeme özellikleri ile sanat tarihi açısından değerlendirilmeye çalışılmıştır.

Geç Osmanlı Dönemine (Laquer, 2010:168; Boşdurmaz- Ödekan- Eldem, 2009: 64-66) ait örnekler olan bu mezar taşlarının 17'si bayan mezarı', 26'sı erkek mezarı', ı'i hem erkek hem bayan mezarı ${ }^{3}$, diğer 3 mezarda $^{4}$ yatanların ise cinsiyetleri bilinmemektedir. Bununla birlikte, başlıklarına bakarak kesin olmamakla birlikte 14 nolu mezarın erkek, 26 nolu mezarın ise bayan mezarı olması muhtemeldir. 21 ve 37 nolu bayan mezarları içerisinde birden fazla cenaze olup ilkinde üç kadın yatmaktadır. Bu kadınların sadece isimleri verilmiş kitabede birbirleri ile akrabalık dereceleri belirtilmemiştir. 37 nolu mezarda ise mezarı yaptıran kişinin eşi (zevcesi) ve kızı (kerimesi) yani anne-kız yatmaktadır. Bay-bayan olarak düzenlendiği anlaşılan 7 nolu mezar ise baba ve kızına (kerimesi) aittir. Yine 13 nolu mezarda yatan iki bay cenazesi arasındaki münasebet ise tam olarak bilinmemektedir. Kitabeden anlaşıldığı kadarıyla dede ifadesi geçmekte ve bu ikinci ismin daha önce gömüldüğü belirtilmektedir. Belki bu doğrultuda mezarın bir dede-toruna ait olabileceği düşünülebilir ki, bu Kayseri ve çevresinde uygulan bir uygulama olarak karşımıza çıkmaktadır.

Değerlendirilen mezar taşlarının en erken tarihlisi 1709, en geç tarihlisi ise 1913'tür. Bu şahidelerin 9'u XVIIl. yy. aralığına (1709, 1742-(1743-1796)-1767-1769-1787-1791-1794$1798)^{5}$, 31'i XIX yy.'a (1801-1801-1805-1808-1812-1819-1820-1820-1820-1822-1826-1827-1827-

'Mezartaşı no: 1, 7, 17, 18, 21, 24, 29, 30, 31, 32, 33, 35, 36, 37, 41, 43, 44, 45.

${ }^{2}$ Mezartaşı no: 2, 3, 4, 5, 6, 8, 9, 10, 11, 12, 13, 15, 16, 19, 20, 22, 23, 25, 27, 28, 34, 38, 39, 40, 42, 46.

${ }^{3}$ Mezartaşı no: 7 .

${ }^{4}$ Mezartaşı no: 14, 26, 47

${ }^{5}$ Mezartaşı no: 27, 14, 13, 33, 32, 35, 34, 42, 26. 
1832-1834-1835-1836-1837-1841-1845-1848-1855-1860-1860-1865-1874-1880-1887-1892(1894-1839)-(1894-1909) $)^{6}$ ve tek örnekte $(1913)^{7}$ XX. yy.'a tarihlenmektedir. Mezar taşlarından 5 örnekte ${ }^{8}$ kitabe olmasına rağmen üzerinde tarih ibaresi yok iken tek ${ }^{9}$ örnekte ise ne kitabe nede tarih yer almamaktadır.

Gesi Mezarlığında incelenen 47 mezar iki farklı tipte ele alınmıştır. Bunlardan 21'i çatma ${ }^{10}$ lahit mezar (Çoruhlu: 1997: 43-59) olup lahitler genellikle tek veya iki kademeli birer kaide üzerine oturtulmuştur. Bu tip mezarlar, dikdörtgen prizma biçiminde yekpare taş ve bloklardan çatılarak yapılan mezarlardır (Sağıroğlu Aslan, 2003: 23). Diğer 26 mezar ise baş ve ayak şahideleri bulunan toprak mezarlardır". Bu mezarlarda, taşlar ya başucuna ya da hem baş hem ayakucuna doğrudan toprağa dikilmekte ve mezarın üzerine toprak yığılmaktadır (iltar: 2005, 351) İncelenen mezarlar içerisinde sanduka tipli mezara hiç rastlanmamış, 10 örneğin ${ }^{12}$ ise ayaktaşları günümüze gelememiştir.

Bu çalışmada, baş ve ayak şahideleri ile aralarındaki yan taşlarından oluşan çatma lahitler, genellikle birbirine taşlarla geçirilmiş, sadece iki örnek ${ }^{13}$ demirlerle tutturularak çatılmışlardır. Genişlik ve yükseklikleri farklı 20 çatma lahitten 2 lahit $^{14}$ diğer örneklerden boyutları ile geniş, bezeme olarak ise özenle değerlendirilmişlerdir. Çatma lahitlerden diğer $18^{\prime} i^{15}$ ise ilk iki örneğe göre boyut ve bezemede farklı detaylarla şekillenmiş mezarlardır.

Çatma lahitleri oluşturan baş taşları genellikle iki tipte görülmektedir. Bunlar, yekpare taştan yapılmış ve ortalama 1.5-2 m. yükseklikleri ile farklı genişliklere sahip örneklerdir. Baştaşları, altta genellikle kareye yakın dikdörtgen bir alt kısımdan sonra pahlanarak üstte doğru dikdörtgen formlu bir gövde ile şekillenmiştir. Yüzeyleri kitabe kuşakları ile bezenen gövde üzerinde ise bir boyun ve mezarda yatan kişinin kimliği ile ilişkili bir başlıkla şahideler tamamlanmıştır. Gesi Mezarlığında incelenen mezarların 39'i bu ilk tipte oluşturulmuştur ${ }^{16}$. Diğer ikinci gruptaki 8 örnek ise baştaşlarının gövdesi üzerinde bir başlık (serpuş) olmayıp üst kısımda farklı tiplerde (sivri, yuvarlak, dilimli gibi) biçimlenen şahidelerdir ${ }^{17}$.

\footnotetext{
${ }^{6}$ Mezartaşı no: $22,24,8,10,12,45,4,18,31,46,43,44,35,6,39,15,1,30,38,37,5,40,19,41$, $29,20,23,11,2,7,3$.

${ }^{7}$ Mezartaşı no: 17.

${ }^{8}$ Mezartaşı no: 9, 16(eksik), 21, 25, 28.

${ }^{9}$ Mezartaşı no: 47.

${ }^{10}$ Mezartaşı no: 1, 2, 3, 4, 5, 6, 7, 8, 9, 10, 11, 13, 16, 18, 22, 32, 33, 34, 36, 42, 47.

"Mezartaşı no:12, 14, 15, 17, 18, 19, 20, 21, 22, 24, 25, 26, 27, 28, 29, 30, 31, 32, 33, 35, 38, 40, 41, $42,43,44,46,47,48,49$.

${ }^{12}$ Mezartaşı no: $5,10,12,15,21,30,36,38,40,45$.

${ }^{13}$ Mezartaşı no: 2,5 .

${ }^{14}$ Mezartaşı no: 2,5 .

${ }^{15}$ Mezartaşı no: 1, 3, 4, 6, 7, 8, 9, 10, 11, 13, 16, 18, 22, 32, 33, 34, 36, 42, 47.

${ }^{16}$ Mezartaşı no: 1, 2, 3, 4, 5, 6, 7, 8, 9, 10, 11, 12, 13, 14, 15, 16, 17, 18, 19, 20, 21, 22, 23, 24, 25, 26, $27,28,29,34,38,39,40,42,43,44,45,46$.

${ }^{17}$ Mezartaşı no: 30, 31, 32, 33, 35, 36, 37, 41, 47 .
} 
Ayaktaşları ise baştaşları gibi yekpare taşlardan yapılmış olup genellikle aynı formlarda değerlendirilmiş örneklerdir. Ayaktaşlarının boyutları baştaşlarıyla bazen aynı ${ }^{18}$ çoğunlukla da 5-10 cm. arasında değişen farkla daha küçük tutulmuştur. Bu mezarlıktaki ayaktaşlarında sivri kemerle sonlanan şahidelerin sayısı diğer formlara göre daha fazladır. Gesi mezarlığındaki ayaktaşlarının gövdeleri çoğunlukla bezemesiz olup, bezemeli şahidelerin ${ }^{19}$ sayısı çok azdır.

Gesi Mezarlığında incelenen mezarların süsleme programlarına bakıldığında, sadece beş lahitin $^{20}$ yüzeylerinin bezendiği görülmektedir. Bu örneklerden 1 ve 23 nolu lahitlerin yan taşlarının üzeri kademeli silmelerle sınırlanmış ve silmeler şahidelerin alt kısımlarında devam ettirilerek yuvarlak formlu bir kemer oluşturacak şekilde tamamlanmıştır. 2 nolu lahitin yüzeyine boş kartuşlar şeklinde düzenlenen panolar yerleştirilmiş ve iç kısmına şua motifi ile ortasına ay-yıldız işlenmiştir. Yan yüzlerde ikili olarak düzenlenen kartuşlar birbirine bağlanmış vaziyettedir. 22 nolu lahit ise diştan bir silme ile çerçevelenmiş ve içerisi yatay olarak çizgisel tarzda baklava formundaki panolarla hareketlendirilmiştir. Diğer bezemeli örnek ise 5 nolu lahit (1848) olup yine yüzeyi kartuşlar şeklindeki boş panolarla dolgulanmıştır. Genel olarak 2 nolu lahitteki (1892) bezemeye benzese de burada panoların içleri boş olup herhangi bir motife yer verilmemiştir. İncelenen diğer lahitler ise tamamen sade olup taş neredeyse hiç işlenmemiştir.

Bezemenin fazla olmadığı bu mezarlıkta sembolik olarak farklı anlamlar yüklenen motifler (Haseki, 1977: 47) az olup ayaktaşlarında sadece dört örnekte uygulanmıştır. Bunlar 3, 29, 37 ve 47 nolu ayak taşları olup en özelliklisi ise 3 nolu olanıdır. Kaideli bir vazodan helezonlar çizerek çıkan dallar ve üzerine yerleştirilen cennet bahçelerini temsil eden çiçekler, stilize yapraklar ile küpe çiçekleri bitkisel kompozisyonu (Barışta, 2002: 123-136; Akar, 1991: 73-78; Biçici, 2009: 109-150; Doğanay, 1998: 261-267) oluşturmaktadır. Kabir ağacı olarak da bilinen aynı zamanda yaşam ve ölüm sembolü olarak, 29 nolu şahidenin yüzeyinde kaideye yerleştirilen, yukarı doğru daralan üstte farklı şekilde sonlanan selvi (Ersoy, 2002: 91-95; Önder, 1970: 10; Yılmaz, 2010: 19-20) motifi işlenmiştir. 33 nolu şahide yüzeyinde de baş kısmı sağ tarafa eğilmiş bir selvi daha bezenmiştir. Bu selvi diğerinden farklı olarak kök boya ile yapılmış ve günümüzde izleri sağlam olarak kalmıştır. Baştaşları içerisinde 47 nolu şahide yine kabartma şeklinde kaideli ve baş kısmı sağa eğilmiş bir selvi motifi ile bezenmiştir. Selvi ağacının uç kısmının sağa ve sola eğilmesi kutsal varlığa saygı veya teslimiyet ifadesi olduğu ya da rüzgârdan tabiata uygun olarak eğildiği bilinmektedir (Oğuz, 1983: 24-27). Bu motiflerin dişında, 37 nolu baştaşının üst ilk satırı yuvarlak kemerle çerçevelenmiş ve üstte bir kır çiçeği yerleştirilmiştir. 41 nolu baştaşında ise son satırdan önceki panonun soluna stilize yapraklar ve kır çiçeği ile az da olsa hareketlilik sağlanmıştır. Bezemeler farklı derinliklerde yapılan oymalarla şekillenmiş bunun yanı sıra kırmızı kök boyada süslemede kullanılan diğer bir unsurdur.

$\mathrm{Bu}$ araştırmada ele alınan mezarların hemen hepsinin baştaşları üzerinde kitabesi bulunmaktadır. Sadece bir örnek kitabesiz olup baştaşı yüzeyinde yer alan selvi motifin-

\footnotetext{
${ }^{18}$ Mezartaşı no: 3, 9, 11, 19, 34, 46.

${ }^{19}$ Mezartaşı no: 3, 29, 37, 47.

${ }^{20}$ Mezartaşı no: 1, 2, 3, 5, 22.
} 
den dolayı çalışmaya dahil edilmiştir. Baştaşları üzerindeki kitabeleri oluşturan yazı kuşaklarının 4l'si sülüs, 5'i ise ta'lik hatla kabartma tekniğinde yazılmıştır. Bu kitabeler basit silmelerle oluşturan dikdörtgen panolar içerisine genellikle düz satırlar halinde ve tek örnekte ise diyagonal olarak yerleştirilmiştir. Yazı kuşakları üç şahide ${ }^{21}$ üzerinde herhangi bir çerçeve olmaksızın serbest şekilde kabartma veya kazıma olarak da uygulanmıştır. Mezar taşlarındaki ilk satırlarda, "Hüvel'l-Hallaku'l Baki (O yaratandır ebedidir), Hüve'l Baki (O ebedidir), Merhum ve Merhuman (Allah'ın rahmetine kavuşan), Merhum ve Mağfur Leha" gibi yakarışlar en sık kullanılan lafızlardır. Hüvel'l-Hallaku'l Baki, şahideler üzerinde cinsiyet ayrımı olmaksızın tam 24 kitabede $^{22}$ en fazla tekrarlanan yakarış olmuştur. Bazı örneklerde ise doğrudan mezarda yatan kişinin kimlik bilgileri ile başlanıp kitabeler dua ve tarih ibaresi ile tamamlanmıştır. Kimlik bilgilerinde bazen yatanın kendi adı bazen de baba adı ve sülale adları ile birlikte verilmiştir. Kethüda zade, Kayserili Büyük zade, Osman Efendi zade, Halis Efendi zade, Humbaracı zade, Balcı Ağa zade, Tüccar zade, Dai zade, Bölükbaşı zade, Kâtip zade, Toklu zade, Hasır zade, Ağa zade, Mahmut Efendi zade, Bekir Ağa zade bu şahidelerde tespit edilen sülale isimleridir. Erkek mezarlarında "Hacı, Efendi, Ağa, Molla ve Seyyid" gibi unvanlar kullanılırken bayan mezarlarında ise "Hanım" ve daha çokta "Hatun" ibaresi kullanılmıştır. Kullanılan bu unvanlar arasında açık bir kronolojik sıralama çıkmamakta bununla birlikte sosyal konumları arasındaki bir derece farkı olması ihtimalini güçlendirmektedir.

Geç Osmanlı dönemi mezar taşlarındaki kitabelerde, kalıp şeklinde yazılan duaların Gesi Mezarlığında çok az uygulandığı bununla birlikte aile, meslek gibi belirleyici unsurların ise mutlaka işlendiği görülmektedir. Kitabelerden, tüccar, balcı, hasırcı, kâtip, kethüda, humbaracı, bölükbaşı, hafız gibi meslek sahiplerinin olduğu anlaşılmaktadır. Kitabeler, amacına uygun olarak mezarda yatan kişinin kimlik bilgilerinin verildiği bunun yanı sıra ölüm sebepleri, hastalık gibi detayların burada fazla işlenmediği yalın ele alınan unsurlardır. Kısa tutulan kitabelerde ölünün ruhuna istenen duaların dışında serzeniş (Âh Minel Mevt, Âh Ölüm, El Fırâk gibi) (Laqueur, 2010: 81) ve öğütlere de fazla rastlanmamıştır. Bu mezarlıktaki kitabelerde bir üslup birliği olmadığı açıkça görülmektedir, çok basit yazılan örneklerin yanı sıra itinalı bir işçilikle ele alınan örnekler de az değildir $^{23}$. Isş̧̧iliğin farklılaşması mezarda yatan kişinin ekonomik gücü ile alakalı olup herhangi bir sanatçı imzası olmayan şahidelerin yerel ustalar tarafından yapılmış olmaları muhtemeldir. Osmanlıca yazılan bu kitabelerin bazılarında yazım ve tamlama hataları yapıldığı da görülmektedir. Giriş cümleleri ise arapça olarak yazılmıştır.

Mezarda yatan kişi ile ilgili önemli bilgilerin verildiği unsurlardan biri de hiç şüphesiz başlıklardır. Dönemlere göre farklılıklar gösteren başlıklar ölen kişinin mesleği ve mensup olduğu sosyal sınıfı hakkında gerçek bilgiler veren en güvenilir unsurlardır (Çal, 2000:206-225; Sürün, 2006: 303-397). Bu mezarlıkta incelenen 31 erkek mezar taşındaki serpuşların çoğunluğunu farklı tiplerdeki kavuklar ${ }^{24}$ oluşturmaktadır. Bu kavuk formlu

\footnotetext{
${ }^{21}$ Mezartaşı no: 31, 32, 33.

${ }^{22}$ Mezartaşı no: 1, 3, 4, 5, 6, 8, 11, 17, 18, 19, 22, 23, 24, 26, 28, 31, 36, 37, 38, 39, 40, 41, 45, 46.

${ }^{23}$ Mezartaşı no: 1, 2, 3, 5, 8, 22, 36, 43, 44, 45.

${ }^{24}$ Mezartaşı no: 2, 5, 7, 8, 9, 10, 12, 13, 14, 15, 16, 19, 22, 23, 25, 27, 28, 34, 38, 40, 42, 46.
} 
tepelikler arasında en yoğun kullanılanlar ise orta dereceli memur ve esnaflara ait çubuk başlıklı olanlardır. Erkek başlıklarında kullanılan diğer tip ise sarıklardır ${ }^{25}$.

Kadın baştaşlarının tepelikleri ise genellikle kadın zarafetine uygun güzellikte zarif olarak tasarlanmaya çalışılıışıır. Bu araştırmada değerlendirilen 9 kadın mezarında kullanılan tepelikler genellikle hotoz ${ }^{26}$ ve tek örnekte vazodan çıkan soyut yapraklardan oluşan bitkisel ${ }^{27}$ başıı kullanılmışıır. Erkek ve kadın mezarlarındaki şahidelerin bazıları ise başlıksız olarak dilimli ${ }^{28}$, üçgen ${ }^{29}$ yuvarlak $^{30}$ veya sivri ${ }^{31}$ gibi farklı formlarda değerlendirilmişlerdir. Şahideler üzerindeki başlıklardan bazıları ${ }^{32}$ iş̧̧ilik olarak kaba olup detayların tam işlenmediği ya da işlenemediği önemli bir ayrıntıdır. Başlıklarda temel tiplerin biçimsel özelliklerdeki detaylara göre alt tiplere ayrılıyor olması, buradaki işçiliğin basitliği dolayısılla serpuşların muhakkak sınıflandııılmasını zorlaştırmaktadır.

Gesi Mezarlı̆ı̆ında değerlendirilmeye çalışılan bu mezartaşlarının özellikle Kayseri ve civarındaki tarihi mezarlıklarda yer alan mezartaşları ile karşılaştıııldı̆̆ında (Güngör, 1996: 31-33; Sağıroğlu Aslan, 2002: 75-90) merkezdeki Seyyid Burhanneddin Mezarlığı ve yakın çevrede yer alan Talas (Topçu, 2009:158-16ı), Ağırnas, Mimarsinan Kasabası Mezarlı̆̆ı, daha uzak ilçe ve köylerde (Sağıroğlu Aslan, 2003:142-192; Sağıroğlu Aslan, 2007: 429-451; Güngör: 1996, 31-33) bulunan mezartaşlarından daha sade mezartaşı yapma geleneğini devam ettiren örnekler olduğu görülmüştür. İncelenen 47 mezar ve şahidelerde kullanılan malzeme genellikle yöreye özgü kesme küfeki taşıdır. Gesi ve çevresinde önemli taş ocaklarının bulunduğu ve günümüzde hala çalışır durumdaki bu ocaklardan çıkarılan koyu renkli, kırmızımsı taş, neredeyse mezarlıktaki şahidelerde kullanılan tek malzemedir. Bu malzemenin yoğunluğu taşların tek bir merkezden çıkarıldığını doğrular niteliktedir. Yumuşak olan ve kolay işlenebilen bu taş cinsinin tahribat ve erimelere de açık olması şahidelerde bezemenin olmamasının belki de en önemli sebeplerindendir. Ayrıca bu malzemenin kalitesinden dolayı lahit ve şahidelerde tahribatların fazla olduğu görülmektedir. Mezarlıkta koyu renkli taşın dışında farklı olarak kullanılan tek örnek 3 nolu mezarın mermer şahideleridir. Bu örnekte de mermer malzemenin buraya sonradan monte edildiği anlaşılmaktadır ki mezarlıkta bitkisel bezemeli tek örnek olması da önemli bir ayrıntıdır.

\section{Sonuç}

İnsanlığın var olduğu andan itibaren ölünün öbür dünyaya uğurlanması ve gömülmesi tüm toplumlarda en önemli dini ritüeller arasında yerini almıştır. Orta Asya'da Türklerin mezarlarına diktikleri "balbal" denen taşlarla (Çoruhlu, 1993: 36; Aslanapa, 1972: 7-8) başlatılan mezartaşı yapma geleneği, zamana ve dinlere göre şekil değiştirse de hiç kaybolmamış yapılmaya devam ettirilmiştir. Gelenekler ve dönemin üslup özellik-

\footnotetext{
${ }^{25}$ Mezartaşı no: 3, 4, 11.

${ }^{26}$ Mezartaşı no: 17, 18, 21, 24, 26, 29, 43, 44, 45.

${ }^{27}$ Mezartaşı no:ı.

${ }^{28}$ Mezartaşı no: 47.

${ }^{29}$ Mezartaşı no: 32.

${ }^{30}$ Mezartaşı no: 31, 35, 36.

${ }^{31}$ Mezartaşı no: 30, 33, 37, 41.

${ }^{32}$ Mezartaşı no: 6, 11, 14, 16, 20, 30, 39.
} 
leri ile birlikte şekillenen mezar taşları, toplumun kendi öz değerlerini geleceğe taşıyan önemli yazılı belgelerdir. Toplumlara ve kültürlere göre bu gelenek malzeme, bezeme ve biçim olarak değişiklik gösterse de ölen kişiyi kalıcı kılabilmek ve onun adına bir işaret koyabilmek hep en önemli amaç olmuştur.

Gesi Mezarlığındaki tarihi mezar taşları ile ilgili yapılan araştırmada geç Osmanlı dönemine ait olan şahideler, yerel malzeme ile farklı tiplerde şekillenmiş genellikle sade örneklerden oluşmuştur. Mezar taşlarında yoğun olarak kullanılan ikonografik anlamların yüklendiği dini kaynaklı çeşitli motiflerin (selvi, hurma, kandil, gül, asma dalı gibi) buradaki şahideler de fazla uygulanmadığı görülmektedir. Erkek ve bayan mezarlarının yanı sıra mezarlıkta kayıtlı çocuk mezarına da rastlanmamıştır. Mermer malzemenin hemen hiç kullanılmadığı Gesi Mezarlığında, XVIIl.-XIX. yy. aralığına tarihlenen kitabelerden anlaşıldığı kadarıyla yerin kültür tarihi ile o zamanda âlim, irfan sahibi insanların, nüfuzlu ailelerin, askerlerin ve önemli meslek sahiplerinin burada yaşadığı anlaşılmaktadır. Aynı zamanda mezarlıkta Kayseri, Sarımsaklı, Vekse? gibi yakın çevrelerden kimselerinde gömülü olduğu, bazı mezarlara ise birden fazla kişinin defnedildiği yine şahideler üzerindeki kitabelerden çıkarılan ayrıntılardır.

En önemli bezemesi üzerindeki yazıtları olan şahidelerde, kullanılan malzemenin kalitesi ile de bağlantılı olarak mezarlarda tahribat fazladır. Gesi Mezarlığında çoğu ayakta olan şahidelerin yanı sıra yerlerde kırılmış, parçalanmış bakımsız haldeki mezar taşlarının sayısı da az değildir. Bu tarihi belgelerin korunabilmesi için özellikle halk bilinçlendirilmeli ve konuyla ilgili farkındalık oluşturulmalıdır. Ayrıca bu mezarlığa yeni definlerin yapılması, kullanılan malzemenin farklılaşması gibi etkenler hem tarihi dokuya uymamakta hem de şahidelere zarar vermektedir. Bu eserlerin bakımlarının yapılarak, envanterleri çıkarılmalı, fotoğraflanarak kayıt altına alınan şahidelerin müzelere kaldırılmadan özellikle yerlerinde korunmaları gerekmektedir.

Bağlarıyla ünlü olan Gesi'de incelediğimiz bu mezarlıkta, sosyal sınıf olarak üst kademede olan kişilere ait şahidelerin hat ve işçilikleri daha özenli, boyutlarının ise daha büyük tutulduğu görülmektedir. Bununla birlikte şahidelerin mezar taşı yapma geleneğini devam ettiren, gösterişten uzak mütevazı örnekler olduğu bir gerçektir. Ölen kişiyi ölümsüzleştirmek için dikilen bu taşların asıl amacı ise şüphesiz ölenin ruhuna istenilen dualardır. Mezar taşları, sondan yeni bir başlangıca göçün güçlü birer sembolleri olarak, dimdik duruşları ile verdikleri mesajlar önemlidir...

\section{KAYNAKÇA}

AKAR, Azade, "Yüzyıllar Boyunca Mezar Yazıtlarında Süslemeler" Atatürk Konferansları Vl (19731974), Ankara,1991, s.73-78.

ASLANAPA, Oktay, Türk Sanatı, ìstanbul, 1972.

BARIŞTA, Örcün, "Göynük Akşemsettin Türbesi Haziresindeki Bitkisel Bezemeli Kadın Mezar Taşları”, Vl. Ortaçağ ve Türk Dönemi Kazı Sonuçları ve Sanat Tarihi Sempozyumu (8-10 Nisan) Bildiriler, Kayseri, 2002, s.123-136.

BAŞKAN, Seyfi, Karamanoğulları Dönemi Konya Mezartaşları, Ankara, 1996.

BEŞBAŞ, Nejdet, Kayseri, Gesi Akarun Evinin Rölöve, Restitüsyon ve Restorasyon Önerisi, Gazi Üniversitesi Fen Bilimleri Enstitüsü Mimarlık ABD., Yayınlanmamış Yüksek Lisans Tezi, Ankara, 2006. 
Biçici, Kamil, "Tire Müzesinde Bulunan Süslemeli Mezar Taşlarından Bazı Örnekler (XVIII-XX. yy.)", Ankara Üniversitesi, ilahiyat Fakültesi Dergisi, 50: 1, Ankara, 2009, s.109-150.

BOŞDURMAZ, Nurcan - Ödekan Ayla - Eldem Edhem, "Osmanlı Döneminden Günümüze Saraybosna Müslüman Mezar Taşları”, iтü Dergisi/b Sosyal Bilimler, Cilt:6, Sayı:2, Aralık, İstanbul, 2009, s.55-67.

ÇAL, Halit, “istanbul Eyüp’teki Erkek Mezartaşlarında Başlıklar” Tarihi, Kültürü ve Sanatıyla IIl. Eyüpsultan Sempozyumu Tebliğler, istanbul, 2000, s.206-225.

ÇORUHLU, Yaşar, Türk Sanatının ABC'Si, ìstanbul, 1993.

ÇORUHLU, Tülin, "Eyüp Sultan ve Çevresindeki Hazirelerde Bulunan Hançerli Lahitler ve Taş Sandukalar", Tarihi, Kültürü ve Sanatıyla l. Eyüpsultan Sempozyumu Tebliğler, ìstanbul, 1997, s.43-59.

DOĞANAY, Aziz, "Eyüp Sultan Camii Civarındaki Bazı Mezarlıkların Natüralist Üslupta Klasik Devir Süslemeleri”, Tarihi, Kültürü ve Sanatıyla Il. Eyüpsultan Sempozyumu Tebliğler, ìstanbul, 1998, s.261-267.

ERSOY, Ayla, “Eyüp'teki Mezar Taşlarında Servi Ağacı Kültü”, Tarihi, Kültürü ve Sanatıyla V. Eyüpsultan Sempozyumu Tebliğler, ìstanbul, 2002, s.91-95.

GüNGÖR, Harun, “Kayseri ve Çevresinde Bazı Mezar Taşları” Tarih Dünyası Tarih Derg., Ankara, 1996, s.31-33.

HASEKi, Metin, Plastik Açıdan Türk Mezar Taşları, ìstanbul, 1977.

ILTAR, Gazanfer, Giresun ili Sahil Şeridindeki Mezar Taşları, Gazi Üniversitesi Sosyal Bilimler Enstitüsü, Sanat Tarihi ABD., Yayınlanmamış Yüksek Lisans Tezi, Ankara, 2005.

iMAMOĞLU, Vacit, Gesi Evleri, Kayseri, 2010.

KARAMAĞARALI, Beyhan, Ahlat Mezar Taşları, Ankara, 1992.

LAQUER, Peter Hans, Hüve'l-Baki, İstanbul'da Osmanlı Mezarlıkları ve Mezar Taşları, İstanbul, 2010.

MERMUTLU, Bedri- Hasan Basri Öcalan, Tarihi Bursa Mezar Taşları 1 Bursa Hazireleri, Bursa, 2011.

OĞUZ, Burhan, Mezar taşında Simgeleşen İnançlar, İstanbul, 1983.

ÖNDER, Mehmet, “Konya Mezar Taşlarında Şekil ve Süsler” Türk Etnografya Dergisi, S.XII-1969, Ankara, 1970, s.5-16.

ÖZDOĞAN, Kazım, Kayseri Tarihi Kültür ve Sanat Eserleri, C.ı, Kayseri, 1948.

SAĞıROĞLU, Aslan Aslı, “Kayseri'deki Eski Mezarlıklar” Vl. Ortaçağ ve Türk Dönemi Kazı Sonuçları ve Sanat Tarihi Sempozyumu (8-10 Nisan) Bildiriler, Kayseri, 2002, s.75-94.

SAĞıROĞLU, Aslan Aslı, Kayseri Zamantı Irmağı Çevresindeki Bezemeli Mezar Taşları, Erciyes Üniversitesi Sosyal Bilimler Enstitüsü, Sanat Tarihi Ana Bilim Dalı, Yüksek Lisans Tezi, Kayseri, 2003.

SAĞıROĞLU, Aslan Aslı, Develi ilçesindeki Bezemeli Mezar Taşları, Kayseri, 2007.

Sürün Mustafa, İstanbul Şeyh Vefa Cami Haziresi (Mezar Taşları Tipolojisi Üzerine Bir Deneme), Marmara Üniversitesi Türkiyat Araştırmaları Enstitüsü Türk Sanatı ABD., Yayınlanmamış Yüksek Lisans Tezi, ìstanbul, 2006.

Topçu Sultan Murat, "Talas ilç̧e Mezarlığında (Cemil Baba Mezarlı̆̆ı) Yer Alan Bezemeli Mezar Taşları", Adıyaman Üniversitesi Sosyal Bilimler Enstitüsü Dergisi, Yıl:2, S.3, Adıyaman, 2009, s.158-161.

Yılmaz Hayri, İstanbul'daki Türk İnanç Kaynaklı Motifli Tarihi Mezar Taşlarının Bozulma Nedenleri ve Restorasyon Yöntemleri, Gazi Üniversitesi Fen Bilimleri Enstitüsü, Yapı Eğitimi ABD. Yayınlanmamış Yüksek Lisans Tezi, Ankara, 2010. 